\title{
Synthesis, Characterization, and DNA-Binding Studies of Nitro(oligopyridine)ruthenium(II) Complexes
}

\author{
Konstantina Karidi, ${ }^{, \neq}$Achilleas Garoufis, ${ }^{*, \dagger}$ Nick Hadjiliadis, ${ }^{*, \dagger}$ Martin Lutz,§ Anthony L. Spek,§ and \\ Jan Reedijk‡,\| \\ Laboratory of Inorganic and General Chemistry, Department of Chemistry, University of \\ Ioannina, Ioannina 45110, Greece, Bijvoet Center for Biomolecular Research, Crystal and \\ Structural Chemistry, Utrecht University, Padualaan 8, 3584 CH Utrecht, Netherlands, and Leiden \\ Institute of Chemistry, Gorlaeus Laboratories, Leiden University, P.O. Box 9502, 2300 RA Leiden, \\ The Netherlands
}

Received May 10, 2006

\begin{abstract}
The complexes of general formulas $\left[\mathrm{Ru}^{\prime \prime}(\text { terpy })\left(4-\mathrm{CO}_{2} \mathrm{H}-4^{\prime}-\mathrm{Mebpy}\right)(\mathrm{X})\right]^{n+}\left(\mathrm{X}=\mathrm{NO}(n=3)\right.$ and $\left.\mathrm{NO}_{2}(n=1) ; 1,2\right)$ and [Rull(terpy)(4-COGHK-4'-Mebpy)(X)] $\left(X=N O(n=3)\right.$ and $\left.\mathrm{NO}_{2}(n=1) ; 3,4\right)$ were synthesized and characterized. The complex $\left[\mathrm{Ru}^{\prime \prime}\left(\right.\right.$ terpy) $\left.\left(4-\mathrm{CO}_{2}-4^{\prime}-\mathrm{Mebpy}\right)\left(\mathrm{NO}_{2}\right)\right]+7.5 \mathrm{H}_{2} \mathrm{O}$ has also been characterized by $\mathrm{X}$-ray crystallographic studies. It crystallizes in the triclinic system: $a=9.4982(1) \AA, b=13.1330$ (1) $\AA, c=14.2498(2)$ $\AA ; \alpha=110.5870(6) \times b c, \beta=98.4048(5) \times b c, \gamma=106.4353(5), P \overline{1}, Z=2$. The crystal structure reveals an extended hydrogen-bonding network. Two water molecules form strong hydrogen bonds with the nitro and the carboxylic oxygen atoms of two separate units of the complex, resulting in a dimeric unit. The dimers are bridged by a $\left(\mathrm{H}_{2} \mathrm{O}\right)_{15}$ cluster, consisting of two cyclo- $\left(\mathrm{H}_{2} \mathrm{O}\right)_{6}$ species, while an exo- $\mathrm{H}_{2} \mathrm{O}(8)$ connects them. Two more exo$\mathrm{H}_{2} \mathrm{O}$ molecules are joined together and connect the cyclo- $\left(\mathrm{H}_{2} \mathrm{O}\right)_{6}$ units with the $\mathrm{H}_{2} \mathrm{O}(1)$ of the dimeric unit. It was found that complexes 1 and 3 can be transformed into their nitro derivatives in aqueous media at neutral pH. Photorelease of $\mathrm{NO}$ in dry MeCN solutions was observed for complexes 1 and 3. Also, complex 2 partially releases $\left(\mathrm{NO}_{2}\right)^{-}$in MeCN upon visible light irradiation. Complex 2 interacts with short fragments (70-300 bp) of calf thymus DNA shortening slightly the apparent polynucleotide length, while the conjugation of the peptide GHK to it (2) affects its DNA-binding mode. The peptide moiety of complex 4 was found to interact with the DNA helix in a synergistic way with the whole complex. Preliminary results of photocleavage of DNA by complex 2 are also reported.
\end{abstract}

\section{Introduction}

A large number of ruthenium nitrosyl complexes containing polypyridine ligands, such as $2,2^{\prime}$-bipyridine (bpy) or $2,2^{\prime}: 6^{\prime}, 2^{\prime \prime}$-terpyridine (terpy), have been synthesized and extensively studied over the past few years. ${ }^{1-4}$ Among them,

* To whom correspondence should be addressed. E-mail: nhadjis@uoi.gr (N.H.); agaroufi@uoi.gr (A.G.). Phone: +30 2651098420 (N.H.); +30 2651098409 (A.G.). Fax: +30 2651044831 (N.H.); +30 2651044831 (A.G.).

University of Ioannina.

$\doteqdot$ Leiden University.

$\S$ Utrecht University.

"E-mail: reedijk@chem.leidenuniv.nl. Phone: 3171527 4459. Fax: 31715274671

(1) Ford, P. C.; Wecksler, S. Coord. Chem. Rev. 2005, 249, 1382.

(2) Ford, P. C.; Laverman, L. E. Coord. Chem. Rev. 2005, 249, 391.

(3) McCleverty, J. A. Chem. Rev. 2004, 104, 403.

(4) Ford, P. C.; Lorkovic, I. M. Chem. Rev. 2002, $102,993$. complexes with possible uses as regulators of blood pressure $^{5,6}$ or as antitumor agents releasing the NO within tumor cells ${ }^{7,8}$ have been suggested. However, a crucial question, concerning to the stability of the coordinated $\mathrm{NO}$ in aqueous media of biological systems, still remains. An exciting question is whether such complexes exist as nitrosyl or whether they are transformed into their nitro forms. It seems that it depends not only on the nature of the ruthenium coordination sphere, but also on the nature of the co-ligands.

(5) Lopes, L. G. F.; Wieraszko, A.; El-Sherif, Y.; Clarke, M. J. Inorg. Chim. Acta 2001, 312, 15.

(6) Lang, D. R.; Davis, J. A.; Lopes, L. G. F.; Ferro, A. A.; Vasconcellos, L. C. G.; Franco, D. W.; Tfouni, E.; Wieraszko, A.; Clarke, M. J. Inorg. Chem. 2000, 39, 2294.

(7) Karidi, K.; Garoufis, A.; Tsipis, A.; Hadjiliadis, N.; den Dulk, H.; Reedijk, J. Dalton Trans. 2005, 1176.

(8) Slocik, J. M.; Shepherd, R. E. Inorg. Chim. Acta 2000, 311, 80. 
Thus, the nitrosyl complexes $\left[\mathrm{Ru}^{\mathrm{II}}(\operatorname{trpy})(\mathrm{dpk}) \mathrm{NO}\right]^{3+}(\mathrm{dpk}=$ $2,2^{\prime}$-dipyridylketone $){ }^{9}\left[\mathrm{Ru}^{\mathrm{II}}(\operatorname{trpy})(\mathrm{L}) \mathrm{NO}\right]^{3+}\left(\mathrm{L}=2,2^{\prime}\right.$-dipyridylamine $){ }^{10}$ and $\left[\mathrm{Ru}^{\mathrm{II}}(\operatorname{trpy})(\mathrm{L}) \mathrm{NO}\right]^{3+}(\mathrm{L}=$ various substituted azopyridine ligands) ${ }^{11}$ are stable in the solid state and in dry organic solvents, but in contact with water they are transformed into their nitro derivatives. On the other hand, similar complexes such as $\left[\mathrm{Ru}^{\mathrm{II}}(\operatorname{trpy})\left(\mathrm{L}^{\prime}\right) \mathrm{NO}\right]^{3+}\left(\mathrm{L}^{\prime}=2-(2-\right.$ pyridyl)azole derivatives) are unusually stable in aqueous media. ${ }^{12}$ In fact, all the above complexes have the same ruthenium coordination sphere consisting of five nitrogen donor atoms from pyridine rings and the nitrogen atom from NO. Moreover, ruthenium nitrosyls with a similar coordination sphere may photorelease the coordinated NO in aqueous media. $^{13,14}$

The noncoordination DNA binding and the photoreactivity of ruthenium polypyridine complexes have been the subject of research interest in the past few years. ${ }^{15-19}$ These coordination compounds are able to bind to DNA in different modes (electrostatically, surface or groove binding, intercalation) depending on the ligand size and nature, and the chirality of the octahedral complex. The most studied compound, $\left[\mathrm{Ru}(\mathrm{bpy})_{3}\right]^{2+}$, shows a rather weak association with DNA, most probably due to its electrostatic interactions with the DNA phosphates. ${ }^{20-22}$ In order to enhance the DNA binding of $\left[\mathrm{Ru}(\mathrm{bpy})_{3}\right]^{2+}$, peptides or amino acids have been tethered to a bpy ligand, forming chimerical complexes, able to bind with higher affinity to DNA, and assisted by an additional peptide-DNA interaction. ${ }^{23-30}$ The nature of the peptide affects both the DNA binding affinity and the cross-

(9) Kar, S.; Sarkar, B.; Ghumaan, S.; Janardanan, D.; van Slageren, J.; Fiedler, J.; Puranik, V. G.; Sunoj, R. B.; Kaim, W.; Lahiri, G. K. Chem.-Eur. J. 2005, 11, 4901.

(10) Chanda, N.; Sarkar, B.; Kar, S.; Fiedler, J.; Kaim, W.; Lahiri, G. K. Inorg. Chem. 2004, 43, 5128.

(11) Mondal, B.; Paul, H.; Puranik, V. G.; Lahiri, G. K. J. Chem. Soc., Dalton Trans. 2001, 481.

(12) Chanda, N.; Paul, D.; Kar, S.; Mobin, S. M.; Datta, A.; Puranik, V. G.; Rao, K. K.; Lahiri, G. K. Inorg. Chem. 2005, 44, 3499.

(13) Patra, A. K.; Mascharak, P. K. Inorg. Chem. 2003, 42, 7363.

(14) Bordini, J.; Hughes, D. L.; Neto, J. D. D.; da Cunha, C. J. Inorg. Chem. 2002, 41, 5410 .

(15) Ji, L. N.; Zou, X. H.; Liu, J. G. Coord. Chem. Rev. 2001, 216, 513.

(16) Kane-Maguire, N. A. P.; Wheeler, J. F. Coord. Chem. Rev. 2001, 211, 145.

(17) Erkkila, K. E.; Odom, D. T.; Barton, J. K. Chem. Rev. 1999, 99, 2777.

(18) Xiong, Y.; Ji, L. N. Coord. Chem. Rev. 1999, 186, 711.

(19) O'Neill, M. A.; Barton, J. K. In Long-Range Charge Transfer in DNA I; 2004; Vol. 236.

(20) Kumar, C. V.; Barton, J. K.; Turro, N. J. J. Am. Chem. Soc. 1985, 107, 5518.

(21) Yamagishi, A. J. Phys. Chem. 1984, 88, 5709.

(22) Yamagishi, A. J. Chem. Soc., Chem. Commun. 1983, 572.

(23) Copeland, K. D.; Lueras, A. M. K.; Stemp, E. D. A.; Barton, J. K. Biochemistry 2002, 41, 12785.

(24) Copeland, K. D.; Fitzsimons, M. P.; Houser, R. P.; Barton, J. K. Biochemistry 2002, 41, 343.

(25) Sardesai, N. Y.; Lin, S. C.; Zimmermann, K.; Barton, J. K. Bioconjugate Chem. 1995, 6, 302.

(26) Sardesai, N. Y.; Zimmermann, K.; Barton, J. K. J. Am. Chem. Soc. 1994, 116, 7502 .

(27) Peek, B. M.; Ross, G. T.; Edwards, S. W.; Meyer, G. J.; Meyer, T. J.; Erickson, B. W. Int. J. Pept. Protein Res. 1991, 38, 114.

(28) Myari, A.; Hadjiliadis, N.; Garoufis, A. Bioinorg. Chem. Appl. 2005, 3, 109 .

(29) Myari, A.; Hadjiliadis, N.; Garoufis, A. J. Inorg. Biochem. 2005, 99, 616.

(30) Myari, A.; Hadjiliadis, N.; Garoufis, A. Eur. J. Inorg. Chem. 2004, 1427. linking efficiency of the ruthenium-peptide conjugated complex..$^{28-30}$ Concerning the DNA photocleavage, it has been suggested that the distance between the bound complex and the DNA helix plays a key role, since the life of the active oxygen species generated by the photoactivation of the ruthenium polypyridine complex is strongly distance dependent. ${ }^{31,32}$ For this reason, complexes containing ligands that bind tightly to DNA (e.g., intercalators) have shown an acceleration of the photoclevage process compared to groove bound complexes. ${ }^{31}$ However, in the case of the chimeric complex $\left[\mathrm{Ru}(\text { bpy })_{2}(\right.$ phenIA $\left.)\right]\left(\mathrm{PF}_{6}\right)_{2}$ (phenIA $=N$-iodoacetyl5-amino-1,10-phenanthroline) containing a 54-residue peptide, which is conjugated to the phenIA ligand, no photoinduced DNA damage was observed..$^{33}$

In the present report an attempt to investigate how polypyridine nitrosyl ruthenium complexes interact with the DNA upon photoactivation is described. For this reason, the complexes $\left[\mathrm{Ru}^{\mathrm{II}} \text { (terpy) }\left(4-\mathrm{CO}_{2} \mathrm{H}-4^{\prime}-\mathrm{Mebpy}\right)(\mathrm{X})\right]^{n+}(\mathrm{X}=\mathrm{NO}$ $(n=3)$ and $\left.\mathrm{NO}_{2}(n=1) ; \mathbf{1}, 2\right)$ and $\left[\mathrm{Ru}^{\mathrm{II}}(\right.$ terpy $)(4-\mathrm{COGHK}-$ $4^{\prime}$-Mebpy $\left.)(\mathrm{X})\right]\left(\mathrm{X}=\mathrm{NO}(n=3)\right.$ and $\left.\mathrm{NO}_{2}(n=1) ; \mathbf{3}, \mathbf{4}\right)$ were synthesized and characterized by spectroscopic and crystallographic techniques. The photochemistry of complexes 1, 2, and $\mathbf{3}$ was studied in dry $\mathrm{MeCN}$, as was their stability in aqueous media. Since only the nitro derivatives were found to be stable, DNA binding interactions were studied with complexes $\mathbf{2}$ and $\mathbf{4}$ in order to investigate the role of the conjugated peptide in the DNA-binding mode. Finally, complex 2 was irradiated with visible light to examine its DNA photocleavage.

\section{Experimental Section}

(i). Materials and Methods. $2,2^{\prime}: 6^{\prime}, 2^{\prime \prime}$-Terpyridine was purchased from Aldrich Chemical Co. and used without further purification. The complex $\mathrm{Ru}\left(\right.$ terpy) $\mathrm{Cl}_{3}{ }^{34}$ and the ligand 4-carboxy$4^{\prime}$-methyl-2,2'-bipyridine (4- $\mathrm{CO}_{2} \mathrm{H}-4^{\prime}$-Mebpy $)^{27}$ were prepared according to literature procedures. The complex $\left[\mathrm{Ru}^{\mathrm{II}}(\mathrm{terpy})\left(4-\mathrm{CO}_{2} \mathrm{H}-\right.\right.$ $\left.\left.4^{\prime}-\mathrm{Mebpy}\right) \mathrm{Cl}\right]\left(\mathrm{PF}_{6}\right)$ was prepared and purified by a literature method. ${ }^{35}$ The complex [Ru(terpy)(4-COGHKCONH $\left.{ }_{2}-4^{\prime}-\mathrm{Mebpy}\right)-$ $\mathrm{Cl}]\left(\mathrm{PF}_{6}\right)$ was prepared by solid-phase synthesis as previously described. ${ }^{36}$ The sonication of the calf thymus DNA was performed according to the literature. ${ }^{37}$ The DNA concentration, expressed as moles of nucleotides per liter [P], was determined on a Pharmacia LKB-Biochrom $4060 \mathrm{UV}$-vis spectrophotometer from the absorbance at $260 \mathrm{~nm}\left(\epsilon_{60}=6600 \mathrm{M}^{-1} \times \mathrm{cm}^{-1}, T=298 \mathrm{~K}\right)$. The sample was found to be consistent with low protein content as the value of the $A_{260} / A_{280}$ ratio was 1.9 .

The infrared spectra of the complexes were recorded on a PerkinElmer Paragon 1000 FTIR spectrophotometer, equipped with a

(31) Hergueta-Bravo, A.; Jimenez-Hernandez, M. E.; Montero, F.; Oliveros, E.; Orellana, G. J. Phys. Chem. B 2002, 106, 4010.

(32) Garcia-Fresnadillo, D.; Georgiadou, Y.; Orellana, G.; Braun, A. M.; Oliveros, E. Helv. Chim. Acta 1996, 79, 1222.

(33) Lasey, R. C.; Banerji, S. S.; Ogawa, M. Y. Inorg. Chim. Acta 2000, $300,822$.

(34) Sullivan, B. P.; Calvert, J. M.; Meyer, T. J. Inorg. Chem. 1980, 19 , 1404.

(35) Hartshorn, C. M.; Maxwell, K. A.; White, P. S.; DeSimone, J. M.; Meyer, T. J. Inorg. Chem. 2001, 40, 601 .

(36) Karidi, K.; Garoufis, A.; Hadjiliadis, N.; Reedijk, J. Dalton Trans. 2005, 728 .

(37) Catte, A.; Marincola, F. C.; Casu, M.; Saba, G.; Lai, A. J. Biomol. Struct. Dyn. 2002, 20, 99. 
Golden Gate Diamond ATR device, using the diffuse reflectance technique. $\mathrm{C}, \mathrm{H}$, and $\mathrm{N}$ determinations were performed on a PerkinElmer 2400 series II analyzer. The ${ }^{23} \mathrm{Na} \mathrm{NMR}$ and ${ }^{31} \mathrm{P}$ NMR spectra were obtained on a Bruker 300 DPX spectrometer operating at 121.49 and $79.39 \mathrm{MHz}$ for ${ }^{31} \mathrm{P}$ and ${ }^{23} \mathrm{Na} \mathrm{NMR}$, respectively, at 310 $\mathrm{K}$ in $\mathrm{D}_{2} \mathrm{O}$ solutions. The LC-MS experiments were performed on a Finnigan MAT TSQ-700 instrument with a custom-made electrospray interface (ESI) combined with LC-equipment consisting of a Dionex pump P580, a Gilson 119 UV-detector at 214 and 254 $\mathrm{nm}$, and an Alltima C18 $150 \mathrm{~mm} \times 4.6 \mathrm{~mm}$ i.d. column. UV-vis spectra were recorded on a Varian Cary 3-Bio spectrophotometer with temperature controller. The irradiation of the solutions was carried out with a Philips mercury lamp. CD spectra were recorded on a Jobin Yvon CD-6 instrument at room temperature.

(ii). Synthesis of the Complexes. Synthesis of [Ru' ${ }^{\mathrm{II}}($ terpy)(4$\mathbf{C O}_{2} \mathrm{H}_{-4}$-Mebpy)NO]( $\left.\mathbf{P F}_{6}\right)_{3}$ (1). A $500 \mathrm{mg}(0.68 \mathrm{mmol})$ portion of $\left[\mathrm{Ru}\right.$ (terpy) $\left.\left(4-\mathrm{CO}_{2} \mathrm{H}-4^{\prime}-\mathrm{Mebpy}\right) \mathrm{Cl}\right]\left(\mathrm{PF}_{6}\right)$ was suspended in $10 \mathrm{~mL}$ of water, and the solution was refluxed for $15 \mathrm{~min}$. The deep redbrown solution was filtered hot and then cooled to room temperature. The $\mathrm{pH}$ of the solution was adjusted to $\sim 2$ with the appropriate amount of $1 \mathrm{M} \mathrm{HCl}$. A $1 \mathrm{~mL}$ portion of aqueous solution containing $47 \mathrm{mg}(0.68 \mathrm{mmol})$ of sodium nitrite, $\mathrm{NaNO}_{2}$, was added slowly over a $10 \mathrm{~min}$ period. After complete addition, the brownred solution became yellow and was warmed at $60{ }^{\circ} \mathrm{C}$ for an additional $45 \mathrm{~min}$. A $4 \mathrm{~mL}$ solution of saturated $\mathrm{NH}_{4} \mathrm{PF}_{6}$ was added, and the precipitate was collected by filtration, washed with diethyl ether, and dried in vacuo (yield 58\%). $\mathrm{C}_{27} \mathrm{H}_{21} \mathrm{~F}_{18} \mathrm{~N}_{6} \mathrm{O}_{3} \mathrm{P}_{3} \mathrm{Ru}(\%)$ calcd: C 32.00, H 2.09, N 8.29. Found: C 31.34, H 2.23, N 8.23.

Synthesis of $\left[\mathrm{Ru}^{\mathrm{II}}\left(\right.\right.$ terpy) $\left.\left(4-\mathrm{CO}_{2} \mathrm{H}-4^{\prime}-\mathrm{Mebpy}\right) \mathrm{NO}_{2}\right]\left(\mathrm{PF}_{6}\right)$ (2). A $500 \mathrm{mg}(0.68 \mathrm{mmol})$ portion of $\left[\mathrm{Ru}^{\mathrm{II}}(\right.$ terpy $)\left(4-\mathrm{CO}_{2} \mathrm{H}-4^{\prime}-\mathrm{Mebpy}\right)-$ $\mathrm{Cl}]\left(\mathrm{PF}_{6}\right)$ was suspended in $10 \mathrm{~mL}$ of water, and the solution was refluxed for $15 \mathrm{~min}$. The deep red-brown solution was filtered hot and then cooled to room temperature. The $\mathrm{pH}$ of the solution was adjusted to $\sim 10$ with $1 \mathrm{M} \mathrm{NaOH}$, and then $1 \mathrm{~mL}$ of an aqueous solution containing $47 \mathrm{mg}(0.68 \mathrm{mmol})$ of sodium nitrite, $\mathrm{NaNO}_{2}$, was added dropwise over a $10 \mathrm{~min}$ period. The brown-red solution becomes orange, and it is warmed at $60{ }^{\circ} \mathrm{C}$ for an additional 30 $\mathrm{min}$. After cooling at room temperature, a $4 \mathrm{~mL}$ solution of saturated $\mathrm{NH}_{4} \mathrm{PF}_{6}$ was added. The precipitate was collected by filtration, washed with diethyl ether, and dried in vacuo (yield 52\%). ESIMS: $m / z 595$, $\left[\mathrm{Ru}^{\mathrm{II}} \text { (terpy) }\left(4-\mathrm{CO}_{2} \mathrm{H}-4^{\prime}-\mathrm{Mebpy}\right)\left(\mathrm{NO}_{2}\right)\right]^{+} . \mathrm{C}_{27} \mathrm{H}_{21} \mathrm{~F}_{6} \mathrm{~N}_{6} \mathrm{O}_{4}-$ PRu (\%)calcd: C 43.85, H 2.86, N 11.36. Found: C 43.34, H 2.63, $\mathrm{N}$ 11.02. ${ }^{1} \mathrm{H}$ NMR $\left(300 \mathrm{MHz}, \mathrm{D}_{2} \mathrm{O}\right)$ isomer $\mathrm{I}: \delta=2.62(\mathrm{~s}, 3 \mathrm{H}$, bpy-Me), 9.45 (d, 1H, bpy-H6), 8.08 (d, 1H, bpy-H5), 8.75 (s, 1H, bpy-H3), 7.32 (d, 1H, bpy-H6'), 7.21 (d, 1H, bpy-H5'), 8.43 (s, 1H, bpy-H3'), 8.27 (d, 2H, tpy-H6H6'), 7.84 (t, 2H, tpy-H5H5'), 7.18 (t, 1H, tpy-H4), 7.18 (t, 1H, tpy-H4'), 7.62 (d, 1H, tpy-H3), 7.62 (d, 1H, tpy-H3'), 8.41 (d, 1H, tpy-H3"), 8.17 (m, 1H, tpyH4"), 8.41 (d, 1H, tpy-H5").

Isomer II: $\delta=2.24$ (s, 3H, bpy-Me), 7.07 (d, 1H, bpy-H6), 6.79 (d, 1H, bpy-H5), 8.14 (s, 1H, bpy-H3), 9.17 (d, 1H, bpy-H6'), 7.68 (d, 1H, bpy-H5'), 8.51 (s, 1H, bpy-H3'), 8.27 (d, 2H, tpyH6H6'), 7.84 (t, 2H, tpy-H5H5'), 7.18 (t, 1H, tpy-H4), 7.18 (t, 1H, tpy-H4'), 7.62 (d, 1H, tpy-H3), 7.62 (d, 1H, tpy-H3'), 8.42 (d, 1H, tpy-H3"), 8.17 (m, 1H, tpy-H4"), 8.42 (d, 1H, tpy-H5").

Synthesis of [Ru' ${ }^{\mathrm{II}}\left(\right.$ terpy)(4-COGHKCONH ${ }_{2}-4^{\prime}$-Mebpy)(NO)]$\left(\mathbf{P F}_{\mathbf{6}}\right)_{\mathbf{3}} \mathbf{( 3 )}$. The synthesis of complex $\mathbf{3}$ was made in a similar way to complex 1. A $100 \mathrm{mg}(0.106 \mathrm{mmol})$ portion of $\left[\mathrm{Ru}^{\mathrm{II}}(\right.$ terpy $)(4-$ $\mathrm{COGHKCONH}_{2}-4^{\prime}$-Mebpy) $\left.\mathrm{Cl}\right] \mathrm{Cl}$ and $0.5 \mathrm{~mL}$ of an aqueous solution containing $7.3 \mathrm{mg}$ of sodium nitrite, $\mathrm{NaNO}_{2},(0.106 \mathrm{mmol})$ were used for this reaction (yield 55\%). $\mathrm{C}_{41} \mathrm{H}_{44} \mathrm{~F}_{18} \mathrm{~N}_{13} \mathrm{O}_{5} \mathrm{P}_{3} \mathrm{Ru}(\%)$ calcd C, 36.89; H, 3.32; N, 13.64. Found: C, 36.97; H, 3.43; N, 13.12. FTIR $(\mathrm{KBr}): v(\mathrm{NO})=1924 \mathrm{~cm}^{-1}(\mathrm{~s})$.
Synthesis of $\left[\mathrm{Ru}^{\mathrm{II}}\left(4-\mathrm{COGHKCONH} \mathbf{H}_{2}-4^{\prime}-\mathrm{Mebpy}\right)\left(\mathrm{NO}_{2}\right)\right]\left(\mathrm{PF}_{6}\right)$ (4). The synthesis of complex $\mathbf{4}$ was performed in a similar fashion

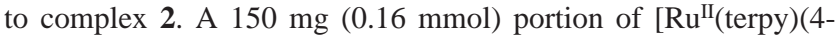
$\mathrm{COGHKCONH}_{2}-4^{\prime}$-Mebpy)Cl] $\mathrm{Cl}$ and $1 \mathrm{~mL}$ of aqueous solution containing $11.04 \mathrm{mg}(0.16 \mathrm{mmol})$ of sodium nitrite, $\mathrm{NaNO}_{2}$, were used for this reaction (yield 60\%). ESI-MS: $m / z, 916\left[\mathrm{Ru}^{\mathrm{II}}(\right.$ terpy)(4-COGHKCONH $\left.{ }_{2}-4^{\prime}-\mathrm{Mebpy} \mathrm{NO}_{2}\right]^{+}$. $\mathrm{C}_{41} \mathrm{H}_{44} \mathrm{~F}_{6} \mathrm{~N}_{13} \mathrm{O}_{6} \mathrm{PRu}(\%)$ calcd C, 46.42; H, 4.18; N, 17.16. Found: C, 46.17; H, 4.13; N, 17.09. ${ }^{1} \mathrm{H}$ NMR (300 MHz, $\mathrm{D}_{2} \mathrm{O}$ ) isomer I: $\delta=3.02$ (s, 3H, bpy-Me), 9.29 (d, 1H, bpy-H6), 7.79 (d, 1H, bpy-H5), 8.32 (s, 1H, bpy-H3), 8.51 (d, 1H, bpy-H6'), 8.25 (d, 1H, bpy-H5'), 8.21 (s, 1H, bpyH3'), 8.10 (d, 2H, tpy-H6H6'), 7.65 (t, 2H, tpy-H5H5'), 8.07 (t, $1 \mathrm{H}$, tpy-H4), 8.07 (t, 1H, tpy-H4'), 8.31 (d, 1H, tpy-H3), 8.31 (d, 1H, tpy-H3'), 7.27 (d, 1H, tpy-H3"), 7.73 (m, 1H, tpy-H4"), 7.27 (d, 1H, tpy-H5"), 8.35 (s, 1H, H2-His), 6.78 (s, 1H, H5-His), 4.70 (d, 1H, $\alpha$-His), 3.58 (t, 1H, $\beta$-His), 3.94 (s, 1H, $\alpha$-Gly), 3.50 (d, 1H, $\alpha$-Lys), 1.97 (m, 1H, $\beta$-Lys), 1.47 (m, 1H, $\gamma$-Lys), 2.04 (m, $1 \mathrm{H}, \delta$-Lys), 3.02 (t, $1 \mathrm{H}, \epsilon$-Lys).

Isomer II: $\delta=2.73$ (s, 3H, bpy-Me), 8.37 (d, 1H, bpy-H6), 7.93 (d, 1H, bpy-H5), 7.29 (s, 1H, bpy-H3), 9.04 (d, 1H, bpy-H6'), 7.65 (d, 1H, bpy-H5'), 8.05 (s, 1H, bpy-H3'), 7.96 (d, 2H, tpyH6H6'), 7.27 (t, 2H, tpy-H5H5'), 7.93 (t, 1H, tpy-H4), 7.93(t, 1H, tpy-H4'), 8.35 (d, 1H, tpy-H3), 8.35 (d, 1H, tpy-H3'), 7.23 (d, 1H, tpy-H3"), 7.71 (m, 1H, tpy-H4"), 7.23 (d, 1H, tpy-H5"), 8.32 (s, 1H, H2-His), 6.75 (s, 1H, H5-His), 4.66 (d, 1H, $\alpha$-His), 3.53 (t, $1 \mathrm{H}, \beta$-His), 3.84 (s, $1 \mathrm{H}, \alpha$-Gly), 3.17 (d, 1H, $\alpha$-Lys), 1.60 (m, 1H, $\beta$-Lys), 1.40 (m, 1H, $\gamma$-Lys), 2.00 (m, 1H, $\delta$-Lys), $2.96(\mathrm{~m}, 1 \mathrm{H}$, $\epsilon$-Lys).

(iii) Generation of Photoproducts for FTIR Analysis. The 2 $\mathrm{mg}$ portions of the complexes [ $\mathrm{Ru}^{\mathrm{II}}($ terpy $\left.)\left(4-\mathrm{CO}_{2} \mathrm{H}-4^{\prime}-\mathrm{Mebpy}\right) \mathrm{NO}\right]-$ $\left(\mathrm{PF}_{6}\right)_{3}(\mathbf{1})$ and $\left[\mathrm{Ru}^{\mathrm{II}}\right.$ (terpy)(4-COGHKCONH $\left.\left.\mathrm{H}_{2}-4^{\prime}-\mathrm{Mebpy}\right) \mathrm{NO}\right]\left(\mathrm{PF}_{6}\right)_{3}$ (3) were dissolved in degassed $\mathrm{MeCN}(0.5 \mathrm{~mL})$ and irradiated with light from a mercury lamp for $2 \mathrm{~h}$. A stream of argon for the evaporation of the solvent was used, leaving a solid orange residue that was analyzed by infrared spectroscopy.

(iv) Generation of Photoproducts for $\mathbf{U V}-$ Vis Analysis. Solutions $\left(10^{-4} \mathrm{M}\right)$ in degassed $\mathrm{MeCN}$ of the complexes [ $\mathrm{Ru}^{\mathrm{II}}$ (terpy)(4-CO $\left.\left.\mathrm{CO}_{2} \mathrm{H}-4^{\prime}-\mathrm{Mebpy}\right) \mathrm{NO}\right]\left(\mathrm{PF}_{6}\right)_{3}, \quad\left[\mathrm{Ru}^{\mathrm{II}}\right.$ (terpy) $\left(4-\mathrm{CO}_{2} \mathrm{H}-4^{\prime}-\right.$ Mebpy) $\left.\mathrm{NO}_{2}\right]\left(\mathrm{PF}_{6}\right)$, and $\left[\mathrm{Ru}^{\mathrm{II}}\left(\right.\right.$ terpy)(4-COGHKCONH$\left.{ }_{2}-4^{\prime}-\mathrm{Mebpy}\right)-$ $\mathrm{NO}]\left(\mathrm{PF}_{6}\right)_{3}$ were irradiated with a mercury lamp for $3 \mathrm{~h}$. The complexes were dissolved in degassed MeCN $\left(10^{-4} \mathrm{~mol} \mathrm{~L}^{-1}\right)$, and the solutions were placed in a $1 \mathrm{~cm}$ path length quartz cuvette. The photochemistry of $\left[\mathrm{Ru}\right.$ (terpy) $\left.\left(4-\mathrm{CO}_{2} \mathrm{H}-4^{\prime}-\mathrm{Mebpy}\right) \mathrm{NO}\right]\left(\mathrm{PF}_{6}\right)_{3}$ was also studied in phosphoric buffer at $\mathrm{pH}=3$. Successive spectra were recorded to monitor the photolysis of the complexes.

X-ray Crystal Structure Determination of 2. X-ray intensities were measured on a Nonius Kappa CCD diffractometer with rotating anode (graphite monochromator, $\lambda=0.71073 \AA$ ) up to a resolution of $(\sin \theta / \lambda)_{\max }=0.65 \AA^{-1}$ at a temperature of $150 \mathrm{~K}$. The structure was solved with Direct Methods ${ }^{38}$ and refined with SHELXL- $97^{39}$ against $F^{2}$ of all reflections. Non-hydrogen atoms were refined with anisotropic displacement parameters. All hydrogen atoms were located in the difference Fourier map. $\mathrm{C}-\mathrm{H}$ hydrogen atoms were refined with a riding model; $\mathrm{O}-\mathrm{H}$ hydrogen atoms were kept fixed on their located positions. The methyl group at $\mathrm{C} 17$ was found rotationally disordered. Water molecule $\mathrm{O} 8$ was refined with occupancy of 0.5 . Geometry calculations and checking

(38) Altomare, A.; Burla, M. C.; Camalli, M.; Cascarano, G. L.; Giacovazzo, C.; Guagliardi, A.; Moliterni, A. G. G.; Polidori, G.; Spagna, R. J. Appl. Crystallogr. 1999, 32, 115.

(39) Sheldrick, G. M. SHELXL-97. Program for crystal structure refinement; University of Gottingen: Gottingen, Germany, 1997. 
Table 1. Experimental Details of the Crystal Structure Determination of 2

\begin{tabular}{ll}
\multicolumn{1}{c}{ formula } & $\mathrm{C}_{27} \mathrm{H}_{20} \mathrm{~N}_{6} \mathrm{O}_{4} \mathrm{Ru} \cdot 7.5 \mathrm{H}_{2} \mathrm{O}$ \\
fw & 728.68 \\
cryst color & red \\
cryst size $\left[\mathrm{mm}^{3}\right]$ & $0.12 \times 0.12 \times 0.09$ \\
cryst syst & triclinic \\
space group & $P 1(\mathrm{No} .2)$ \\
$a[\AA]$ & $9.4982(1)$ \\
$b[\AA]$ & $13.1330(1)$ \\
$c[\AA]$ & $14.2498(2)$ \\
$\alpha[\mathrm{deg}]$ & $110.5870(6)$ \\
$\beta[\mathrm{deg}]$ & $98.4048(5)$ \\
$\gamma[\mathrm{deg}]$ & $106.4353(5)$ \\
$V\left[\AA \AA^{3}\right]$ & $1535.12(3)$ \\
$\mathrm{Z}$ & 2 \\
$d_{\text {calc }}\left[\mathrm{g} / \mathrm{cm}{ }^{3}\right]$ & 1.576 \\
$\mu\left[\mathrm{mm}{ }^{-1}\right]$ & 0.582 \\
abs correction & $\mathrm{SORTAV}[63]$ \\
abs correction range & $0.90-0.95$ \\
reflns (measured/unique) & $24813 / 6942$ \\
$R_{\text {int }}$ & 0.0475 \\
params/restraints & $416 / 0$ \\
$\mathrm{R} 1 / \mathrm{wR} 2[I>2 \sigma(I)]$ & $0.0341 / 0.0838$ \\
$\mathrm{R} 1 / \mathrm{wR} 2$ [all reflns] & $0.0447 / 0.0899$ \\
$S$ & 1.065 \\
$\rho_{\text {min/max }}\left[\mathrm{e} / \AA^{3}\right]$ & $-0.62 / 1.02$ \\
&
\end{tabular}

for higher symmetry were performed with the PLATON program. ${ }^{40}$ Further experimental details, like absorption correction,${ }^{41}$ are given in Table 1.

Preparation of Ruthenium Adducts with DNA for Electronic and CD Spectra. The interactions of complexes $\left[\mathrm{Ru}^{\mathrm{II}}\right.$ (terpy)(4$\left.\left.\mathrm{CO}_{2} \mathrm{H}-4^{\prime}-\mathrm{Mebpy}\right) \mathrm{NO}_{2}\right]\left(\mathrm{PF}_{6}\right)$ and $\left[\mathrm{Ru}^{\mathrm{II}}\right.$ (terpy)(4-COGHKCONH${ }_{2}-$ 4'-Mebpy) $\left.\mathrm{NO}_{2}\right]\left(\mathrm{PF}_{6}\right)$ with calf thymus DNA were studied with $\mathrm{UV}-$ vis and CD spectroscopy by adding the required volume of a freshly prepared solution of the complexes dissolved in $1 \mathrm{mM}$ PIPES and $20 \mathrm{mM}$ sodium chloride aqueous solution, to calf thymus DNA solutions $(100 \mu \mathrm{M})$ and incubating at $25^{\circ} \mathrm{C}$ for $24 \mathrm{~h}$. The final ruthenium/DNA base pair ratios $(r)$ were $0.1,0.3$, and 0.5 (complex concentration was 10,30 , and $50 \mu \mathrm{M}$ ). CD spectra were also recorded for the study of the irradiation of the system $\left[\mathrm{Ru}^{\mathrm{II}}\right.$ (terpy) $\left.\left(4-\mathrm{CO}_{2} \mathrm{H}-4^{\prime}-\mathrm{Mebpy}\right) \mathrm{NO}_{2}\right]\left(\mathrm{PF}_{6}\right)-\mathrm{DNA}$ at ratio $r=0.1$. Samples of DNA with complex 2 were prepared as above. CD spectra were recorded before and after the irradiation of the solutions with the mercury lamp for $30 \mathrm{~min}$. In this experiment, the effect of the irradiated complex to DNA was also studied. In that case, the sample of complex [ $\mathrm{Ru}^{\mathrm{II}}$ (terpy) $\left.\left(4-\mathrm{CO}_{2} \mathrm{H}-4^{\prime}-\mathrm{Mebpy}\right) \mathrm{NO}_{2}\right]\left(\mathrm{PF}_{6}\right)$ was irradiated with the mercury lamp and subsequently was mixed with the DNA sample.

\section{Results and Discussion}

(i) Synthesis and Characterization of the Complexes. Complexes 1-4 were synthesized following the replacement of the chloride in the corresponding chlorido complexes and the adjustment of the $\mathrm{pH}$ of the reaction to the desired value. The nitrosyl complexes were obtained in acidic conditions $(\mathrm{pH} \sim 2)$ and the nitro in basic conditions $(\mathrm{pH} \sim 10)$. The IR spectra of the prepared nitrosyl complexes $\mathbf{1}$ and $\mathbf{3}$ show strong and sharp IR bands at 1955 and $1924 \mathrm{~cm}^{-1}$, respectively, which were assigned to the stretching vibration frequency $v(\mathrm{NO})$. The $v(\mathrm{NO})$ stretching frequency of $\mathbf{1}$ is very similar to that observed in the complex $\left[\mathrm{Ru}^{\mathrm{II}}(\right.$ terpy)-

(40) Spek, A. L. J. Appl. Crystallogr. 2003, 36, 7

(41) Blessing, R. H. J. Appl. Crystallogr. 1997, 30, 421.
Table 2. Diagnostic Spectroscopic Data for Complexes 1-4

\begin{tabular}{|c|c|c|}
\hline no. & $\begin{array}{c}\text { electronic spectral data } \lambda_{\max }(\mathrm{nm}) \\
\text { in dry MeCN. }\end{array}$ & infrared spectral data $\left(\mathrm{cm}^{-1}\right)$ \\
\hline 1 & $\begin{array}{l}250 \pi \rightarrow \pi^{*} \text { (intraligand) } \\
289 \mathrm{~d}_{\pi}(\mathrm{Ru}) \rightarrow \pi^{*}(\text { terpy }) \\
304 \mathrm{~d}_{\pi}(\mathrm{Ru}) \rightarrow \pi^{*}(\text { bpy }) \\
339 \mathrm{~d}_{\pi}(\mathrm{Ru}) \rightarrow \pi^{*}(\mathrm{NO})\end{array}$ & $\begin{array}{l}v(\mathrm{NO})=1955 \\
v(\mathrm{CO})=1706\end{array}$ \\
\hline 2 & $\begin{array}{l}269,280 \pi \rightarrow \pi^{*} \text { (intraligand), } \\
304 \mathrm{~d}_{\pi}(\mathrm{Ru}) \rightarrow \pi^{*}(\text { terpy }) \\
329 \mathrm{~d}_{\pi}(\mathrm{Ru}) \rightarrow \pi^{*}(\mathrm{bpy}) \\
475 \mathrm{~d}_{\pi}(\mathrm{Ru}) \rightarrow \pi^{*}\left(\mathrm{NO}_{2}\right)\end{array}$ & $\begin{array}{l}v(\mathrm{CO})=1732 \\
v_{\mathrm{as}}\left(\mathrm{NO}_{2}\right)=1419 \\
v_{\mathrm{s}}\left(\mathrm{NO}_{2}\right)=1272\end{array}$ \\
\hline 3 & $\begin{array}{l}270 \pi \rightarrow \pi^{*} \text { (intraligand) } \\
310 \pi \rightarrow \pi^{*} \text { (intraligand) } \\
314 \mathrm{~d}_{\pi}(\mathrm{Ru}) \rightarrow \pi^{*}(\text { terpy }) \\
325 \mathrm{~d}_{\pi}(\mathrm{Ru}) \rightarrow \pi^{*}(\text { bpy }) \\
350 \mathrm{~d}_{\pi}(\mathrm{Ru}) \rightarrow \pi^{*}(\mathrm{NO})\end{array}$ & $\begin{array}{l}v(\mathrm{NO})=1924 \\
v(\mathrm{CO})=1645\end{array}$ \\
\hline 4 & $\begin{array}{l}280 \pi \rightarrow \pi^{*} \text { (intraligand), } \\
306 \mathrm{~d}_{\pi}(\mathrm{Ru}) \rightarrow \pi^{*} \text { (terpy) } \\
330 \mathrm{~d}_{\pi}(\mathrm{Ru}) \rightarrow \pi^{*}(\text { bpy }), \\
473 \mathrm{~d}_{\pi}(\mathrm{Ru}) \rightarrow \pi^{*}\left(\mathrm{NO}_{2}\right)\end{array}$ & $\begin{array}{l}\nu(\mathrm{CO})=1648 \\
v_{\mathrm{as}}\left(\mathrm{NO}_{2}\right)=1437 \\
v_{\mathrm{s}}\left(\mathrm{NO}_{2}\right)=1263\end{array}$ \\
\hline
\end{tabular}

(bpy)NO] ${ }^{3+}\left(1952 \mathrm{~cm}^{-1}\right) .{ }^{42}$ Also, a strong band at $1706 \mathrm{~cm}^{-1}$ assigned to the $v(\mathrm{C}=\mathrm{O})$ stretching vibration indicates that the carboxyl group of the ligand $4-\mathrm{CO}_{2} \mathrm{H}-4^{\prime}-\mathrm{Mebpy}$ is protonated. The conjugation of the peptide GHK in complex 3 affects the value of the $v(\mathrm{NO})$ stretching frequency, which is shifted to lower frequencies by about $30 \mathrm{~cm}^{-1}$. In general, the value of $v(\mathrm{NO})$ is a good indicator of the degree of positive charge residue on the coordinated $\mathrm{NO}^{43}$ Thus, this value decreases upon replacement of the $-\mathrm{CO}_{2} \mathrm{H}$ with - COGHK at the para position of the pyridine ring in the ligand 4- $\mathrm{CO}_{2} \mathrm{H}-4^{\prime}-\mathrm{Mebpy}$, indicating that the electrophilic reactivity of the nitrosyl group could be decreased from complex 3 to 1. This does not seem to be expected, since the electrophilic reactivity of the ruthenium nitrosyl complexes depends on the nature of the inner-sphere coordinated ligands rather than the substituents on the pyridine ring. ${ }^{44}$ In the IR spectra of nitro complexes $\mathbf{2}$ and $\mathbf{4}$, the absence of the $v(\mathrm{NO})$ stretching vibration band indicates the complete transformation of the corresponding nitrosyl complexes to the nitro ones. Also, the $v(\mathrm{C}=\mathrm{O})$ band appeared at 1660 and $1676 \mathrm{~cm}^{-1}$ in the spectra of complexes 2 and 4, respectively, indicating that the carboxyl group of the ligand $4-\mathrm{CO}_{2} \mathrm{H}-$ 4 '-Mebpy in both complexes is deprotonated.

In the electronic spectra of complexes $\mathbf{1}$ and $\mathbf{3}$ in dry $\mathrm{MeCN}$ solutions, the intense bands at 250 and $274 \mathrm{~nm}$ correspondingly are most likely intraligand $\pi \rightarrow \pi^{*}$ transitions. ${ }^{42,45}$ The bands at 289 and $304 \mathrm{~nm}$ in the spectrum of complex 1, which coincide in a broad band at 310 in the case of complex $\mathbf{3}$, are probably MLCT transitions $\mathrm{d}_{\pi} \mathrm{Ru} \rightarrow$ $\pi^{*}$ (ligand). ${ }^{42,46}$ The lowest energy bands at 339 and $350 \mathrm{~nm}$ in the spectra of $\mathbf{1}$ and $\mathbf{3}$, correspondingly, are attributed to the $\mathrm{d}_{\pi} \mathrm{Ru} \rightarrow \pi^{*}(\mathrm{NO})$ transition. ${ }^{42,46}$ The band shifting to lower energies from 1 to 3 reflects the destabilization of the $\mathrm{d}_{\pi}$ level, due to the $\mathrm{d}_{\pi} \mathrm{Ru} \rightarrow \pi^{*}(\mathrm{NO})$ back-bonding, and thus, the electrophilic reactivity decreases going from $\mathbf{3}$ to $\mathbf{1}$. On

(42) Pipes, D. W.; Meyer, T. J. Inorg. Chem. 1984, 23, 2466.

(43) Godwin, J. B.; Meyer, T. J. Inorg. Chem. 1971, 10, 471.

(44) Ershov, A. Y.; Kucheryavyi, P. V.; Nikol'skii, A. B. Russ. J. Gen. Chem. 2004, 74, 651.

(45) Bryant, G. M.; Fergusso, J.; Powell, H. K. J. Aust. J. Chem. 1971, 24, 257.

(46) Callahan, R. W.; Meyer, T. J. Inorg. Chem. 1977, 16, 574. 
Karidi et al.

A.

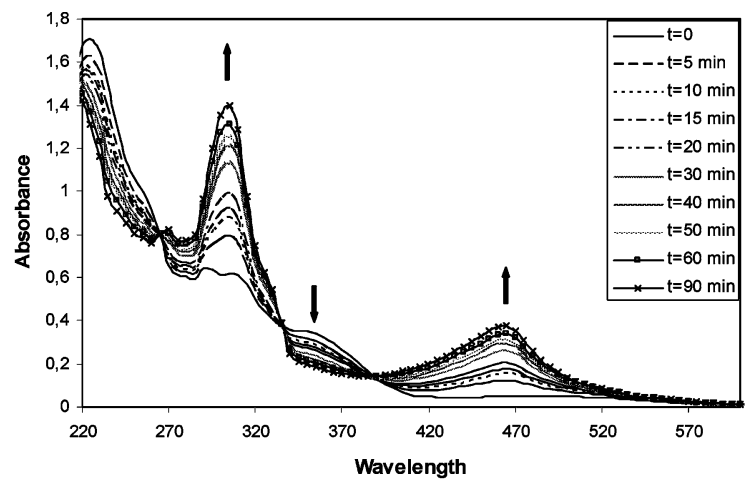

B.

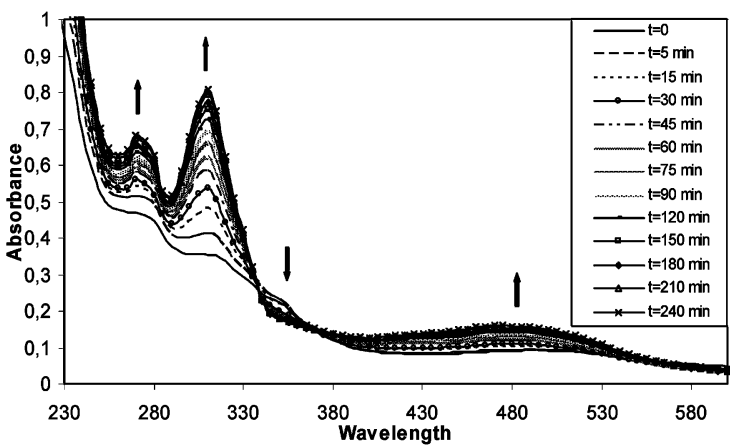

C.

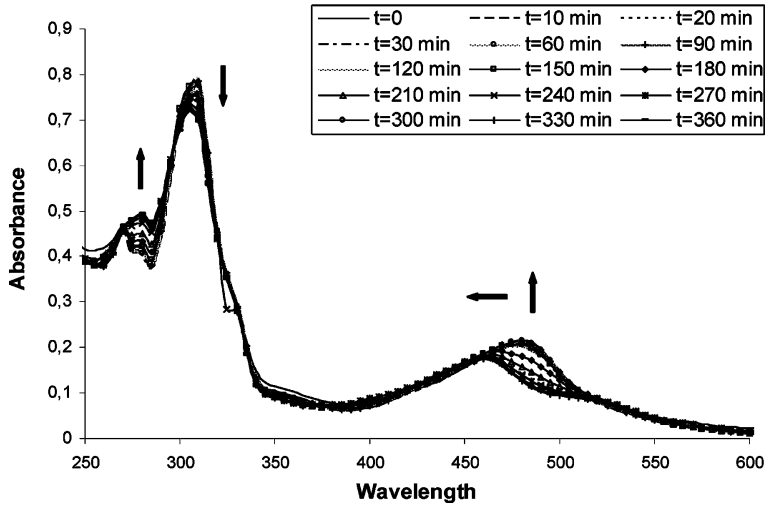

Figure 1. Electronic spectra of complexes 1, 3, and 2 (A, B, and C, respectively), in dry degassed $10^{-4} \mathrm{M} \mathrm{MeCN}$ solutions during light irradiation. Arrows indicate increasing or decreasing of the absorbance intensity.

the other hand, the nitro complexes $\mathbf{2}$ and $\mathbf{4}$ display the MLCT band $\mathrm{d}_{\pi} \mathrm{Ru} \rightarrow \pi^{*}\left(\mathrm{NO}_{2}\right)$ red-shifted at 475 and 473 $\mathrm{nm}$, correspondingly. All relevant spectral data are summarized in Table 2.

The purity of complexes $\mathbf{2}$ and $\mathbf{4}$ was checked by mass spectrometry (MALDI TOF and ESI MS) using MeCN as a carrier solvent. However, in the cases of nitrosyl complexes $\mathbf{1}$ and $\mathbf{3}$, the moisture traces present in the carrier solvent partially transformed them to the corresponding nitro complexes. ${ }^{11}$

(ii) Photochemistry of the Complexes. The photochemistry of nitrosyl complexes $\mathbf{1}$ and $\mathbf{3}$ was studied in carefully dried $\mathrm{MeCN}$ solution $\left(10^{-4} \mathrm{M}\right)$ using light irradiation with a mercury lamp $(150 \mathrm{~W})$. Upon the irradiation, the light orange color of the solutions turned to brown accompanied by changes in their UV-vis spectra. Successive scanning was taken in $10 \mathrm{~min}$ intervals, and the original bands of the complexes were replaced by new ones (Figure 1). Figure

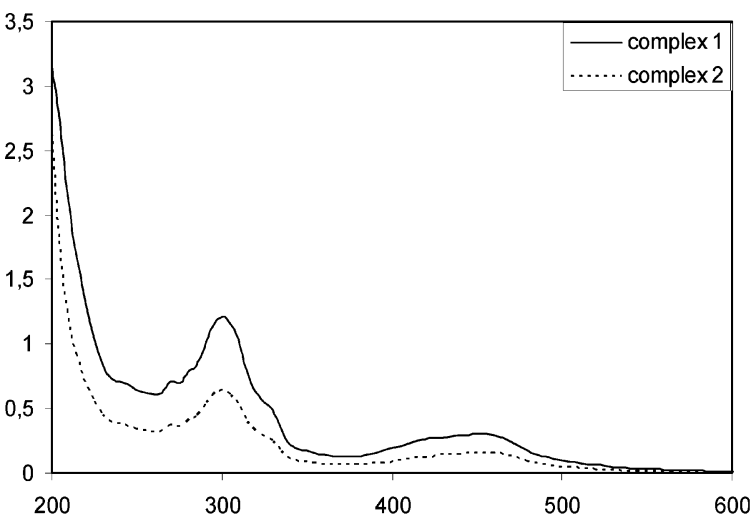

A.

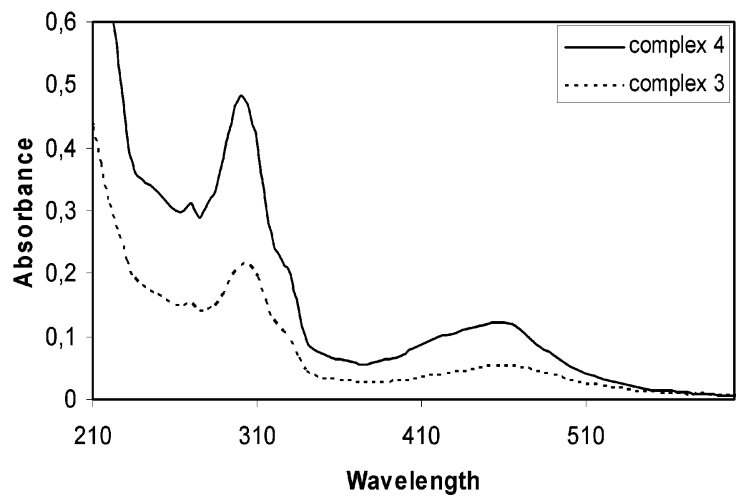

Figure 2. (A) Electronic spectra of complexes $\mathbf{1}$ and $\mathbf{2}$ under the same $\mathrm{pH}$ conditions in consistent buffer at $1 \mathrm{mM}$ PIPES and $20 \mathrm{mM}$ sodium chloride at $25{ }^{\circ} \mathrm{C}$. (B) Electronic spectra of complexes $\mathbf{3}$ and $\mathbf{4}$ under the same $\mathrm{pH}$ conditions in consistent buffer at $1 \mathrm{mM}$ PIPES and $20 \mathrm{mM}$ sodium chloride at $25^{\circ} \mathrm{C}$.

1A demonstrates the spectral changes observed for complex 1. These changes display a clear transformation of the complex to a photoproduct, characterized by three isosbestic points at 265,334 , and $390 \mathrm{~nm}$ indicating that possible intermediates or byproducts are not in significant concentrations to make measurable changes. The MLCT absorption band at $339 \mathrm{~nm}\left(\mathrm{~d}_{\pi} \mathrm{Ru} \rightarrow \pi^{*}(\mathrm{NO})\right)$ decreases, indicative of NO photorelease (Figure 1A). A new low-energy absorption band at $464 \mathrm{~nm}$ is appearing which arises from a $\mathrm{d}_{\pi} \mathrm{Ru} \rightarrow$ $\pi^{*}(\mathrm{MeCN})$ and/or from a $\pi$ (ligand) $\rightarrow \mathrm{d}_{\pi} \mathrm{Ru}$ transition. ${ }^{47}$ The bands at 289 and $304 \mathrm{~nm}\left(\mathrm{~d}_{\pi} \mathrm{Ru} \rightarrow \pi^{*}(\right.$ ligand $\left.)\right)$ were observed broadened and clustered together at $302 \mathrm{~nm}$, while their intensity increased dramatically. The intraligand $\pi \rightarrow$ $\pi^{*}$ transition bands were red-shifted to $269 \mathrm{~nm}$ (see Table 1) which is characteristic of the formation of $\mathrm{Ru}(\mathrm{III})$ species. ${ }^{45}$ In addition, the EPR spectrum of the photoproduct showed paramagnetic species, suggesting the presence of Ru(III). Exhaustive irradiation of the solution leads to a final stable spectrum after $2 \mathrm{~h}$. Similar spectral changes were observed upon irradiation of the MeCN solution of complex 3 (Figure 1B). Two isosbestic points at 338 and $372 \mathrm{~nm}$ were observed, indicating the transformation of the complex to a photoproduct. The MLCT absorption band at $350 \mathrm{~nm}$ increases, while a new broad band at $473 \mathrm{~nm}$ is appearing. The intensities of the intraligand $\pi \rightarrow \pi^{*}$ and the MLCT $\mathrm{d}_{\pi}$ $\rightarrow \pi$ (ligand) bands increase, indicating that the replacement

(47) Luo, Y.; Potvin, P. G.; Tse, Y. H.; Lever, A. B. P. Inorg. Chem. 1996 35,5445 . 
A.

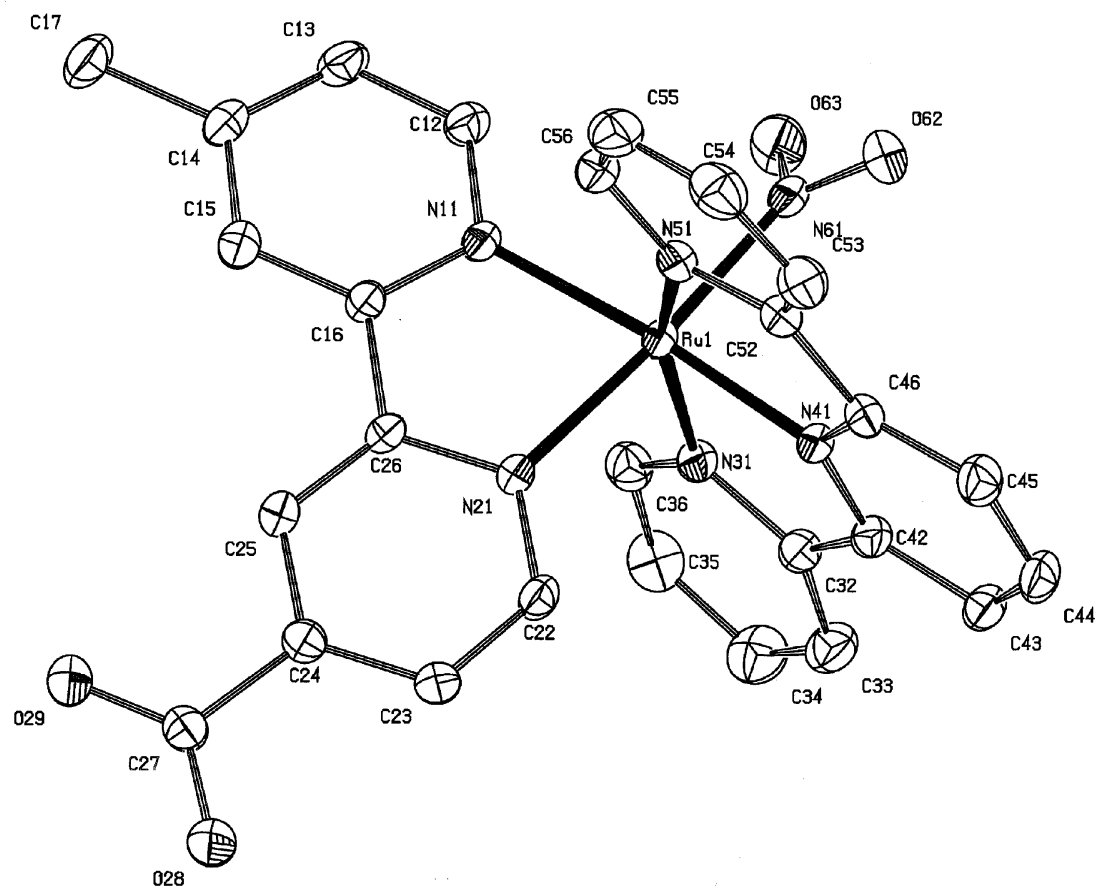

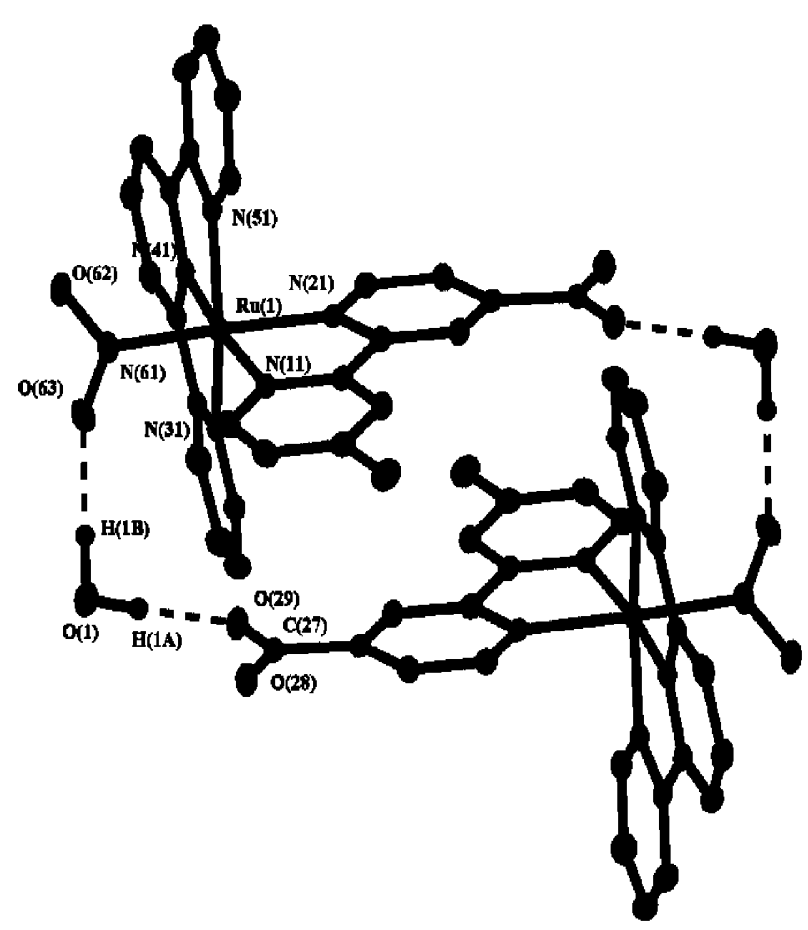

B.

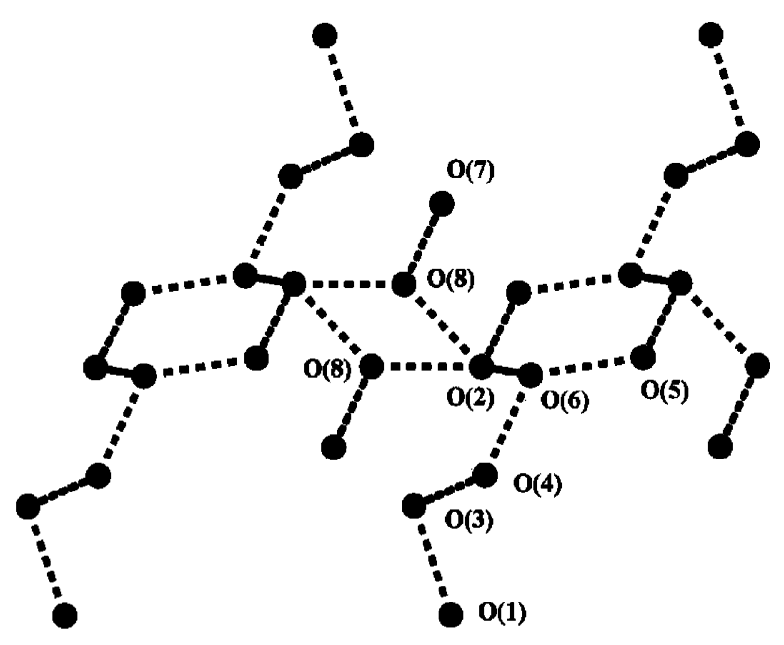

C.

Figure 3. (A) ORTEP diagram of deprotonated complex 2 with $50 \%$ probability thermal ellipsoids showing the atomic labeling scheme. (B) Hydrogen bonding of the dimer. (C) Supramolecular $\left(\mathrm{H}_{2} \mathrm{O}\right)_{15}$ network.

of the $\mathrm{NO}$ is followed by oxidation of the ruthenium center. The NO dissociation from the precursor complex cis- $(\mathrm{Cl}$,$\mathrm{Cl})\left[\mathrm{Ru}^{\mathrm{II}} \mathrm{Cl}_{2}\left(\mathrm{NO}^{+}\right)\right.$(terpy) $] \mathrm{Cl}$ has been previously reported, suggesting a weak coordination of the $\mathrm{MeCN}$ in addition to the oxidation of the ruthenium center. ${ }^{36}$

The photochemistry of the nitro complex (2) was studied in $\mathrm{MeCN}$ solution during the irradiation with a mercury lamp until a final stable spectrum (6 h) was obtained (Figure 1C). Spectral changes in the UV and visible region were observed since the complex was transformed to a photoproduct, characterized by two isosbestic points at 324 and $515 \mathrm{~nm}$. The $\mathrm{d}_{\pi} \rightarrow \pi\left(\mathrm{NO}_{2}\right)$ absorption band is decreasing, and two new bands are appearing at 505 and $464 \mathrm{~nm}$. The MLCT band at $464 \mathrm{~nm}$ is very similar to that observed in the case 
Karidi et al.

Table 3. Selected Bond Distances $[\AA ̊]$ and Angles [deg] for the Deprotonated Complex 2

\begin{tabular}{lccr}
\hline N11-Ru1 & $2.0961(19)$ & N11-Ru1-N51 & $98.46(8)$ \\
N21-Ru1 & $2.0708(19)$ & N11-Ru1-N61 & $97.11(8)$ \\
N31-Ru1 & $2.078(2)$ & N21-Ru1-N31 & $89.77(8)$ \\
N41-Ru1 & $1.9669(19)$ & N21-Ru1-N41 & $96.02(8)$ \\
N51-Ru1 & $2.065(2)$ & N21-Ru1-N51 & $90.63(8)$ \\
N61-Ru1 & $2.029(2)$ & N21-Ru1-N61 & $175.34(7)$ \\
N61-O62 & $1.261(3)$ & N31-Ru1-N41 & $79.48(8)$ \\
N61-O63 & $1.250(3)$ & N31-Ru1-N51 & $159.31(8)$ \\
& & & \\
O62-N61-O63 & $116.7(2)$ & N31-Ru1-N61 & $91.42(8)$ \\
N11-Ru1-N21 & $78.23(7)$ & N41-Ru1-N51 & $79.90(8)$ \\
N11-Ru1-N31 & $101.87(8)$ & N41-Ru1-N61 & $88.63(8)$ \\
N11-Ru1-N41 & $174.04(8)$ & N51-Ru1-N61 & $89.85(8)$
\end{tabular}

of complex 1 and could be attributed to the $d_{\pi} R u \rightarrow \pi^{*}$ $(\mathrm{MeCN})$ transition, while the lowest energy band at $505 \mathrm{~nm}$ is assigned as the MLCT band $\mathrm{d}_{\pi} \rightarrow \pi$ (ligand). In the EPR spectrum of the final photoproduct, paramagnetic species corresponding to $\mathrm{Ru}(\mathrm{III})$ were observed. LC-MS spectrometric analysis of the irradiated solution is showing the formation of a solvolyzed product. The singly charged positive ion at $m / z 675.7$ corresponding to the $\mathrm{C}_{31} \mathrm{H}_{26} \mathrm{~N}_{8} \mathrm{O}_{4}$ $\mathrm{Ru}$ could be assigned to the solvolyzed cation $\left\{\left[\mathrm{Ru}^{\mathrm{III}}(\operatorname{trpy})-\right.\right.$ (4- $\mathrm{CO}_{2}-4^{\prime}$-Mebpy) $\left.(\mathrm{MeCN})\right] \mathrm{NO}_{2} \cdot \mathrm{MeCN}^{+}$, while the related protonated double charged cation $\left\{\left[\mathrm{Ru}^{\mathrm{III}}(\right.\right.$ trpy $)\left(4-\mathrm{CO}_{2} \mathrm{H}-4^{\prime}-\right.$ Mebpy) $(\mathrm{MeCN})] \mathrm{NO}_{2} \cdot \mathrm{MeCN}^{2+}$ appears at $\mathrm{m} / z$ 338.4. Also, a signal at $\mathrm{m} / \mathrm{z} 379.4$ corresponding to the $\mathrm{C}_{29} \mathrm{H}_{23} \mathrm{~N}_{6} \mathrm{O}_{2} \mathrm{~F}_{6}$ $\mathrm{PNaRu}$ could be assigned to the doubly charged sodiumcontaining cation $\left\{\left[\mathrm{Ru}^{\mathrm{III}}\right.\right.$ (trpy) $\left.\left(4-\mathrm{CO}_{2} \mathrm{Na}-4^{\prime}-\mathrm{Mebpy}\right)(\mathrm{MeCN})\right]-$ $\left.\left(\mathrm{PF}_{6}\right)\right\}^{2+}$. The presence of the $\mathrm{Na}^{+}$is likely originating from the addition of $\mathrm{NaOH}$ during the transformation of the precursor chlorido-complex to the nitro derivative. Conclusively in all cases studied, the results confirmed the photoxidation of $\mathrm{Ru}(\mathrm{II})$ to $\mathrm{Ru}(\mathrm{III})$ and the dissociation of the $\mathrm{NO}$ and $\mathrm{NO}_{2}$ in $\mathrm{MeCN}$ solutions according to the following reactions:

$$
\begin{array}{r}
{\left[\mathrm{Ru}^{\mathrm{II}}(\text { trpy })\left(4-\mathrm{CO}_{2} \mathrm{H}-4^{\prime}-\mathrm{Mebpy}\right)(\mathrm{NO})\right]^{3+} \rightarrow\left[\mathrm{Ru}^{\mathrm{III}}(\mathrm{trpy})\right.} \\
\left.\left(4-\mathrm{CO}_{2} \mathrm{H}-4^{\prime}-\mathrm{Mebpy}\right)(\mathrm{MeCN})\right]^{3+}+\mathrm{NO}
\end{array}
$$

$$
\begin{aligned}
& {\left[\mathrm{Ru}^{\mathrm{II}}(\operatorname{trpy})\left(4-\mathrm{CO}_{2}-4^{\prime}-\mathrm{Mebpy}\right)\left(\mathrm{NO}_{2}\right)\right]^{+} \rightarrow\left[\mathrm{Ru}{ }^{\mathrm{III}}(\operatorname{trpy})\right.} \\
&\left.\left(4-\mathrm{CO}_{2}-4^{\prime}-\mathrm{Mebpy}\right)(\mathrm{MeCN})\right]^{3+}+\mathrm{NO}_{2}
\end{aligned}
$$

(iii) Aqueous Media Studies of the Complexes. The frequencies of the $v(\mathrm{NO})$ stretching vibration in complexes 1 and 3 (1955 and $1924 \mathrm{~cm}^{-1}$ ) indicate that the degree of the positive charge residue on the coordinated NO is high. ${ }^{43}$ Such high values reflect the electrophilic reactivity of the NO group. The nucleophilic attack of the hydroxyl group to the NO converts the nitrosyl complexes to corresponding nitro, through eq 3 .

$$
\mathrm{Ru}-\left(\mathrm{NO}^{+}\right)+2 \mathrm{OH}^{-} \leftrightarrow \mathrm{Ru}-\left(\mathrm{NO}_{2}{ }^{-}\right)+\mathrm{H}_{2} \mathrm{O}
$$

In order to study the DNA interactions of complexes 1-4 in aqueous media, the stability of the above compounds at

\begin{tabular}{|c|c|c|c|c|}
\hline $\mathrm{D}-\mathrm{H} \cdots \mathrm{A}$ & $\mathrm{D}-\mathrm{H}$ & $\mathrm{H} \cdots \mathrm{A}$ & $\mathrm{D} \cdots \mathrm{A}$ & $\mathrm{D}-\mathrm{H} \cdots \mathrm{A}$ \\
\hline $\mathrm{O} 1-\mathrm{H} 1 \mathrm{~A} \cdots \mathrm{O} 29^{\mathrm{i} a}$ & 0.93 & 1.80 & $2.727(3)$ & 172 \\
\hline $\mathrm{O} 1-\mathrm{H} 1 \mathrm{~B} \cdots \mathrm{O} 63^{\mathrm{ii}}$ & 1.02 & 1.94 & $2.957(3)$ & 173 \\
\hline $\mathrm{O} 2-\mathrm{H} 2 \mathrm{~A} \cdots \mathrm{O} 28$ & 0.91 & 1.84 & $2.743(3)$ & 172 \\
\hline $\mathrm{O} 2-\mathrm{H} 2 \mathrm{~B} \cdots \mathrm{O}^{\mathrm{iii}}$ & 0.99 & 1.88 & $2.794(3)$ & 152 \\
\hline $\mathrm{O} 3-\mathrm{H} 3 \mathrm{~A} \cdots \mathrm{O} 28^{\mathrm{i}}$ & 0.97 & 1.75 & $2.716(3)$ & 173 \\
\hline $\mathrm{O} 3-\mathrm{H} 3 \mathrm{~B} \cdots \mathrm{O} 1$ & 0.92 & 1.99 & $2.869(3)$ & 160 \\
\hline $\mathrm{O} 4-\mathrm{H} 4 \mathrm{~A} \cdot \cdots \mathrm{O} 62^{\mathrm{iv}}$ & 0.95 & 1.94 & $2.890(3)$ & 172 \\
\hline $\mathrm{O} 4-\mathrm{H} 4 \mathrm{~B} \cdots \mathrm{O}^{\mathrm{v}}$ & 0.93 & 1.86 & $2.784(3)$ & 172 \\
\hline $\mathrm{O} 5-\mathrm{H} 5 \mathrm{~A} \cdots \mathrm{O} 2^{\mathrm{iii}}$ & 1.02 & 1.80 & $2.794(3)$ & 163 \\
\hline 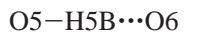 & 0.95 & 1.93 & $2.829(4)$ & 159 \\
\hline $\mathrm{O} 6-\mathrm{H} 6 \mathrm{~A} \cdot \cdots \mathrm{O} 4^{\mathrm{vi}}$ & 0.95 & 1.83 & $2.736(4)$ & 158 \\
\hline O6-H6B $\cdots \mathrm{O} 2$ & 1.06 & 1.90 & $2.868(4)$ & 151 \\
\hline O7-H7A $\cdots{ }^{\mathrm{O}} 8^{\mathrm{vi}}$ & 0.96 & 2.01 & $2.973(8)$ & 174 \\
\hline O7-H7B $\cdots O 62^{\text {vii }}$ & 1.01 & 2.02 & $3.021(3)$ & 168 \\
\hline $\mathrm{O} 8-\mathrm{H} 8 \mathrm{~A} \cdots \mathrm{O} 2^{\mathrm{v}}$ & 1.00 & 1.85 & $2.810(8)$ & 162 \\
\hline $\mathrm{O} 8-\mathrm{H} 8 \mathrm{~B} \cdot \cdot \mathrm{O} 2^{\mathrm{iii}}$ & 1.02 & 2.08 & $2.802(9)$ & 126 \\
\hline
\end{tabular}
neutral $\mathrm{pH}$ was investigated. As presented in Figure 2, the electronic spectra of complexes $\mathbf{1}$ and $\mathbf{2}$ (Figure 2A) are exactly the same, and this is also true for complexes $\mathbf{3}$ and
Table 4. Hydrogen Bonding Interactions in the Crystal Structure of 2

${ }^{a}$ Water molecule O8 was refined with an occupancy of 0.5. Symmetry operations follow: i, $2-x, 1-y, 1-z$; ii, $1+x, y, z ;$ iii, $1-x,-y, 1$ $-z ;$ iv, $-x, 1-y,-z ; \mathrm{v}, x-1, y, z ;$ vi, $1-x, 1-y, 1-z$; vii, $1-x$, $1-y,-z$.

4 (Figure 2B). This effect clearly shows that nitrosyl complexes $\mathbf{1}$ and $\mathbf{3}$ were transformed to the corresponding nitro complex at neutral $\mathrm{pH}$.

The ${ }^{1} \mathrm{H}$ NMR spectra of complexes $\mathbf{1}$ and $\mathbf{2}$ in $\mathrm{D}_{2} \mathrm{O}$ (buffer phosphates, $\mathrm{pH}=7.0$ ) are the same. They show double resonances for the protons of ligand $4-\mathrm{CO}_{2}-4^{\prime}-\mathrm{Mebpy}$ and slightly broadened signals for the terpy, indicating the presence of two chemically nonequivalent species. Assuming that only the nitro complex is present at this $\mathrm{pH}$, a possible explanation could be the existence of two positional isomers (differing in the orientation of the ligand $4-\mathrm{CO}_{2} \mathrm{H}-4^{\prime}-\mathrm{Mebpy}$, toward ruthenium center). ${ }^{35}$ Double resonances for all protons of the ligand 4-COGHK-4'-Mebpy in the spectra of complexes 3 and $\mathbf{4}$ were also observed. The ${ }^{1} \mathrm{H}$ NMR signals of complexes 1-4 were assigned, assisted by TOCSY experiments.

(iv)Crystal and Molecular Structure of Deprotonated Complex 2. The molecular structure of $\mathbf{2}$ is shown in Figure $3 \mathrm{~A}$. Table 3 presents selected bond distances and angles. The crystal structure of the complex consists of neutral units of the complex and water molecules involved in a network of hydrogen bonds. Two symmetry related water molecules $\mathrm{O} 1$ and $\mathrm{O} 1^{\prime}$ link two complex molecules via the nitro oxygen atoms $\mathrm{O}(63) / \mathrm{O}(63)^{\prime}$ and $\mathrm{O}(29) / \mathrm{O}(29)^{\prime}$ to form a centrosymmetric, hydrogen-bonded dimer. The hydrogen bonds in this dimer are strong with $\mathrm{O} \cdots \mathrm{O}$ distances of $2.717(3)$ and 2.957(3) $\AA$, respectively (Table 4, Figure 3B). The dimers are bridged to other dimers by $\left(\mathrm{H}_{2} \mathrm{O}\right)_{15}$ clusters, involving two cyclo- $\left(\mathrm{H}_{2} \mathrm{O}\right)_{6}$ connected by an exo- $\mathrm{H}_{2} \mathrm{O}(8)$ in a half occupancy. Two more exo- $\mathrm{H}_{2} \mathrm{O}$ species are joined together connecting the cyclo- $\left(\mathrm{H}_{2} \mathrm{O}\right)_{6}$ units with the $\mathrm{H}_{2} \mathrm{O}(1)$ of the dimer (Figure 3C). Similar cyclo- $\left(\mathrm{H}_{2} \mathrm{O}\right)_{6}$ in a chairlike conformation have been observed recently in the crystal lattice of various metal complexes. ${ }^{48,9,49,50}$ In the cyclic

(48) Ye, B. H.; Ding, B. B.; Weng, Y. Q.; Chen, X. M. Inorg. Chem. 2004, $43,6866$.

(49) Ghosh, S. K.; Ribas, J.; El Fallah, M. S.; Bharadwaj, P. K. Inorg. Chem. 2005, 44, 3856.

(50) Ghosh, S. K.; Bharadwaj, P. K. Inorg. Chem. 2003, 42, 8250. 
A.

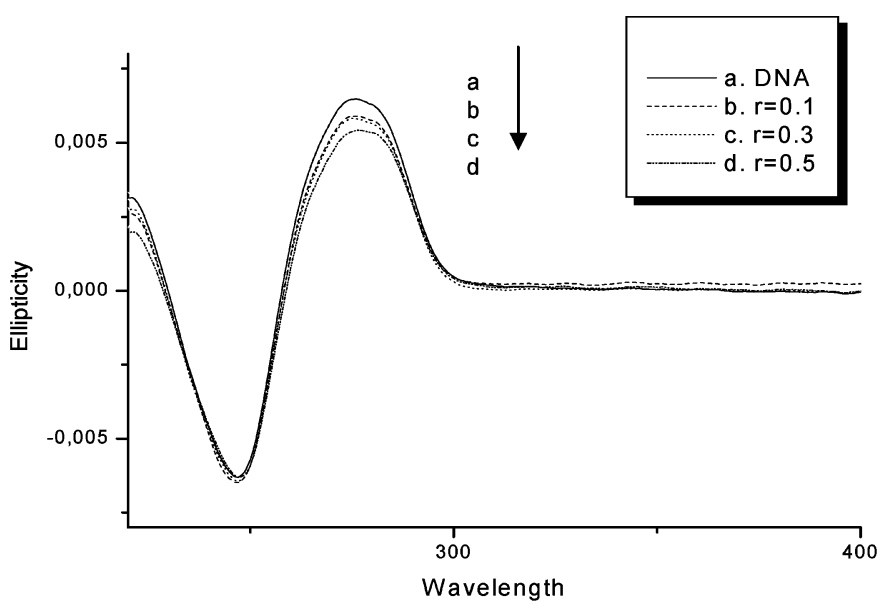

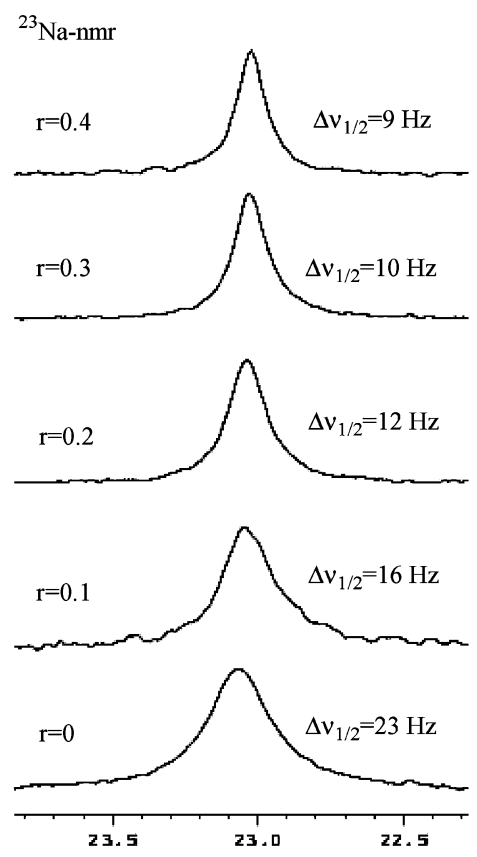

B.

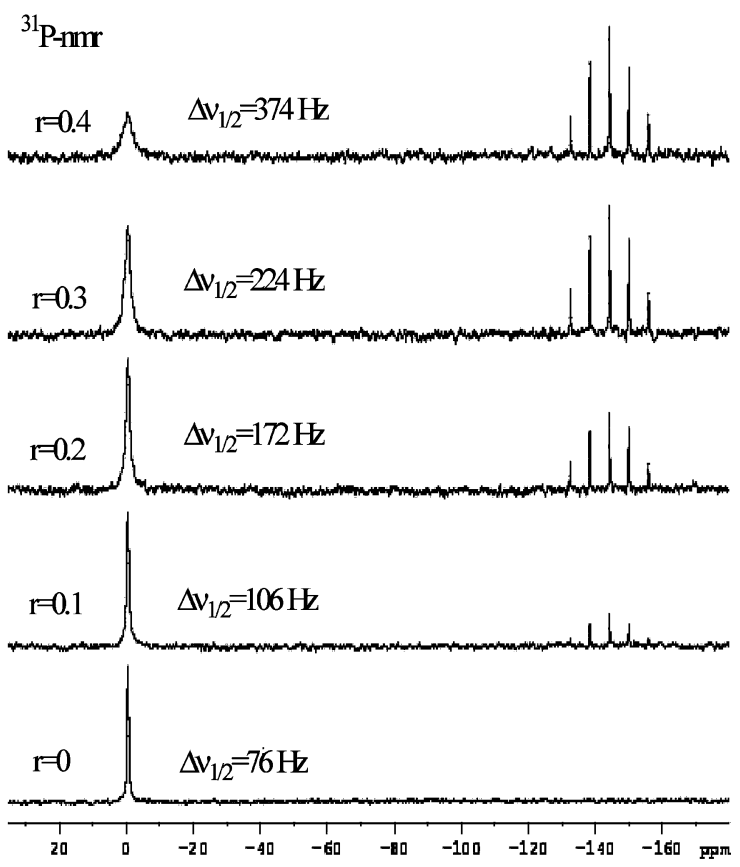

C.

Figure 4. (A) Circular dichroism spectral changes of calf thymus DNA (70-300 bp) upon addition of complex 2 at increasing ratios. The arrow indicates the order from a to c. (B and C) ${ }^{23} \mathrm{Na}$ and ${ }^{31} \mathrm{P}$ NMR spectral changes corresponding to calf thymus DNA (70-300 bp) upon addition of complex 2 at increasing ratios.

arrangement of the $\left(\mathrm{H}_{2} \mathrm{O}\right)_{6}$, the average $\mathrm{O} \cdots \mathrm{O}$ distance is $2.830 \AA$ for complex 2 , which is very close to that observed by $\mathrm{Ye}^{48}$ and slightly shorter than those observed from liquid water $2.854 \AA .{ }^{51}$ However, the value of the average angle $\mathrm{O} \cdots \mathrm{O} \cdots \mathrm{O}$ is $117.60^{\circ}$, which is significantly different from the corresponding value of $109.3^{\circ}$ in hexagonal ice.

The coordination polyhedron of $\mathrm{Ru}(\mathrm{II})$ is distorted octahedral and formed by five pyridinic nitrogen atoms (three nitrogen atoms from terpy and two from the ligand $4-\mathrm{CO}_{2}-$ 4'-Mebpy) and one more nitrogen atom from the anionic nitro group. The distortion from $O_{h}$ symmetry is mainly expressed in the angles with cis angles ranging from 78.23$(7)^{\circ}$ to $101.87(8)^{\circ}$ resulting in an angular variance ${ }^{52}$ of $59.50^{\circ}{ }^{2}$ The $\left(\mathrm{NO}_{2}\right)^{-}$anion is coordinated through the

(51) Speedy, R. J.; Madura, J. D.; Jorgensen, W. L. J. Phys. Chem. 1987, 91, 909.

(52) Robinson, K.; Gibbs, G. V.; Ribbe, P. H. Science 1971, $172,567$. nitrogen, with a $\mathrm{Ru}-\mathrm{N}$ bond length of 2.029(2) $\AA$, which is among the shortest observed in the literature for similar complexes. For example, it is shorter than those observed for the complexes $\left[\mathrm{Ru}^{\mathrm{II}}(\right.$ trpy $)\left(2,2^{\prime}\right.$-dipyridylamine $\left.)\left(\mathrm{NO}_{2}\right)\right]$ $\left(\mathrm{ClO}_{4}\right), 2.034 \AA{ }^{53}\left[\mathrm{Ru}^{\mathrm{II}}\right.$ (trpy)(arylazopyridine) $\left.\left(\mathrm{NO}_{2}\right)\right]\left(\mathrm{ClO}_{4}\right)$, $2.057 \AA,^{11}\left[\mathrm{Ru}^{\mathrm{II}}(\mathrm{trpy})\left(\mathrm{PMe}_{3}\right)_{2}\left(\mathrm{NO}_{2}\right)\right]\left(\mathrm{ClO}_{4}\right), 2.074 \AA{ }^{54}$ and [Ru ${ }^{\mathrm{II}}($ trpy $)(1-\mathrm{Me}-2$-(2-pyridyl) $1 H$-benzimidazole $\left.)\left(\mathrm{NO}_{2}\right)\right]$ $\left(\mathrm{ClO}_{4}\right){ }^{12}$ The $\mathrm{N}(61)-\mathrm{O}(62)$ and $\mathrm{N}(61)-\mathrm{O}(63)$ bond distances are quite longer than those observed for similar complexes, ${ }^{12,55}$ probably due to the involvement of the $\mathrm{O}(63)$ in the hydrogen-bonding network. For the same reason, the $\mathrm{C}(27)-\mathrm{O}(28)$ and $\mathrm{C}(27)-\mathrm{O}(29)$ bond distances of the

(53) Chanda, N.; Mobin, S. M.; Puranik, V. G.; Datta, A.; Niemeyer, M.; Lahiri, G. K. Inorg. Chem. 2004, 43, 1056.

(54) Leising, R. A.; Kubow, S. A.; Churchill, M. R.; Buttrey, L. A.; Ziller, J. W.; Takeuchi, K. J. Inorg. Chem. 1990, 29, 1306.

(55) Sarkar, S.; Sarkar, B.; Chanda, N.; Kar, S.; Mobin, S. M.; Fiedler, J.; Kaim, W.; Lahiri, G. K. Inorg. Chem. 2005, 44, 6092. 
Karidi et al.

A.

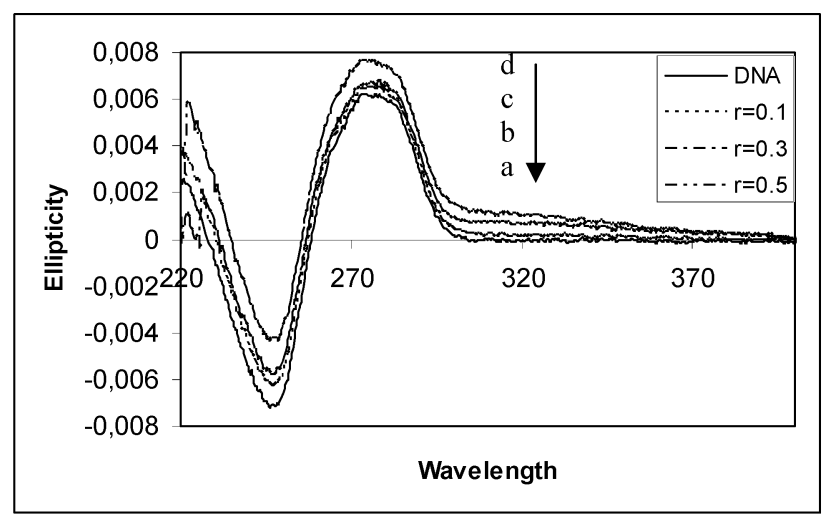

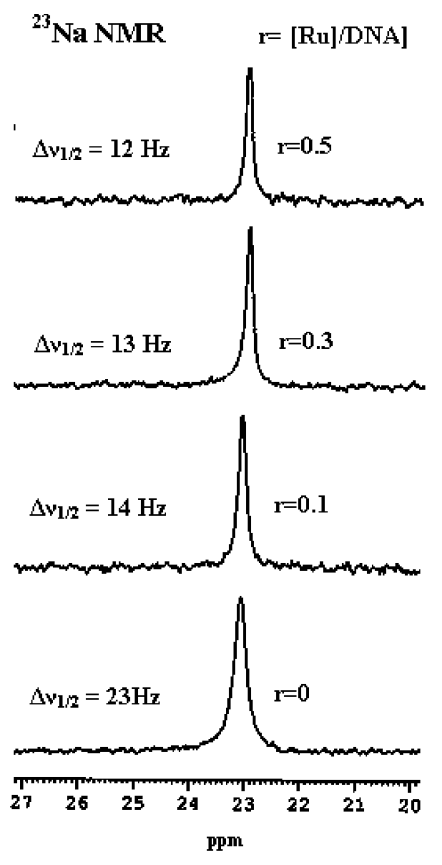

B.

\section{9 ppm}

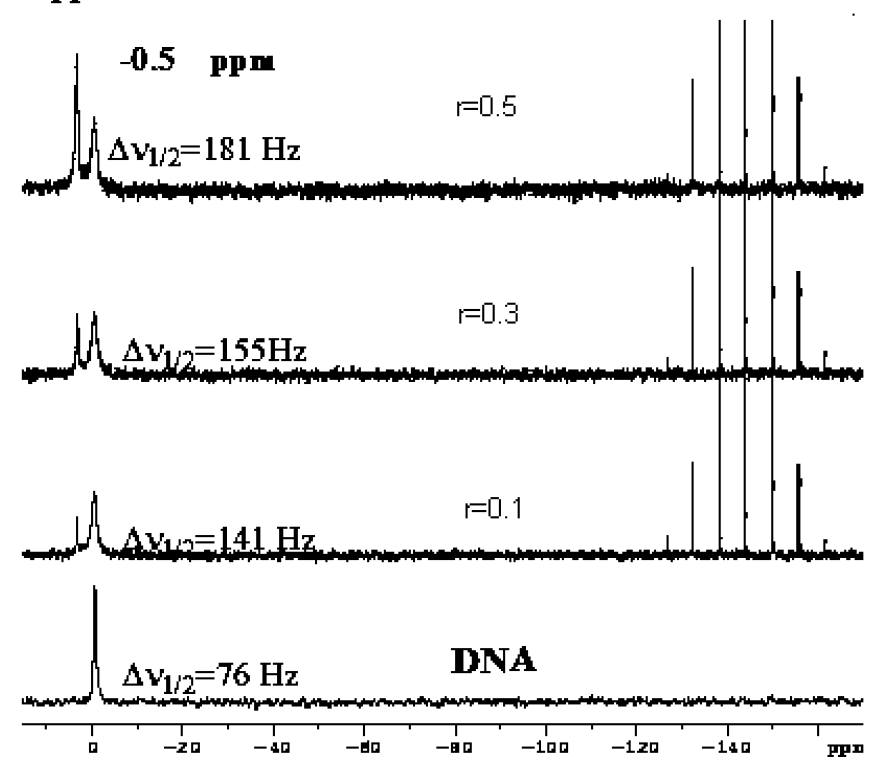

C.

Figure 5. (A) Circular dichroism spectral changes of calf thymus DNA (70-300 bp) upon addition of complex 4 at increasing ratios. The arrow indicates the order from a to c. (B and C) ${ }^{23} \mathrm{Na}$ and ${ }^{31} \mathrm{P}$ NMR spectral changes corresponding to calf thymus DNA (70-300 bp) upon addition of complex 4 at increasing ratios.

carboxylic group are slightly longer than expected. The central pyridine ring of terpy is coordinated to metal center with a bond length of $\mathrm{N}(41)-\mathrm{Ru}(1)=1.967(2) \AA$ which is significantly shorter from the corresponding distances of the other two outmost terpy's pyridine rings. However, these values are in the average range for such complexes, ${ }^{11,53,54,12,55}$ and very similar to those observed for complex [ $\mathrm{Ru}^{\mathrm{II}}(\mathrm{trpy})-$ (4- $\left.\left.\mathrm{CO}_{2} \mathrm{H}-4^{\prime}-\mathrm{Mebpy}\right) \mathrm{Cl}\right]^{+} .{ }^{35}$ As mentioned above (subsection iii), the ligand $4-\mathrm{CO}_{2} \mathrm{H}-4^{\prime}-$ Mebpy is able to coordinate to the metal center in two different orientations. The observation that in the isolated crystals the $4-\mathrm{CO}_{2} \mathrm{H}-4^{\prime}-$ Mebpy possesses a trans- $\left(\mathrm{CO}_{2}, \mathrm{NO}_{2}\right)$ arrangement can be explained by the stability of dimers that are formed through hydrogen bonds which could not be formed in the case of the cis arrangement. In the case of complex $\left[\mathrm{Ru}^{\mathrm{II}}(\operatorname{trpy})\left(4-\mathrm{CO}_{2} \mathrm{H}-4^{\prime}-\mathrm{Mebpy}\right) \mathrm{Cl}\right]^{+}$, where no dimers are formed even though the carboxylic group is protonated, the ligand $4-\mathrm{CO}_{2} \mathrm{H}-4^{\prime}-$ Mebpy prefers a cis- $\left(\mathrm{Cl}, \mathrm{CO}_{2}\right)$ orientation. ${ }^{35}$ The two $\mathrm{Ru}-\mathrm{N}$ bond distances of the ligand 4- $\mathrm{CO}_{2}-4^{\prime}$-Mebpy are not equal, with the $\mathrm{Ru}-$
(1) $-\mathrm{N}(11)$ bond length being 2.096(2) $\AA$ and $\mathrm{Ru}(1)-\mathrm{N}(21)$, 2.071(2) $\AA$ (Figure 3A). It has been suggested that such differences consist of a trans influence of the shorter $\mathrm{Ru}-\mathrm{N}$ terpy bond (1.967(2) $\AA$ ) to the opposite $\mathrm{Ru}-\mathrm{N}$ bond, which is significantly elongated. ${ }^{35}$ Similar behavior was also observed with complex [Ru $\left.{ }^{\mathrm{II}}(\operatorname{trpy})\left(4-\mathrm{CO}_{2} \mathrm{H}-4^{\prime}-\mathrm{Mebpy}\right) \mathrm{Cl}\right]^{+}$ where the $\mathrm{Ru}-\mathrm{N}$ bond distance of the $4-\mathrm{CO}_{2} \mathrm{H}$ substituted pyridinic ring which is trans to the shorter $\mathrm{Ru}-\mathrm{N}$ (terpy) bond is longer than the $4^{\prime}$-Me substituted ring. ${ }^{35}$ However, in the trans position to the shorter $\mathrm{Ru}-\mathrm{N}$ (terpy) pyridine ring of the ligand $4-\mathrm{CO}_{2}-4^{\prime}$-Mebpy is the $4^{\prime}$-Me-substituted and not the $-\mathrm{CO}_{2} \mathrm{H}$ pyridine ring. This demonstrates clearly the minor role of the substitution in the pyridine ring, compared to the influence of the trans-effect.

(v) DNA Binding Studies. In order to investigate the roles of the conjugated peptide and the nitro group of the prepared complexes to their interactions with calf thymus DNA (70$300 \mathrm{bp})$, spectroscopic (CD, ${ }^{23} \mathrm{Na}$ and $\left.{ }^{31} \mathrm{P} \mathrm{NMR}\right)$ and analytical techniques were used. As mentioned above, the 
A.

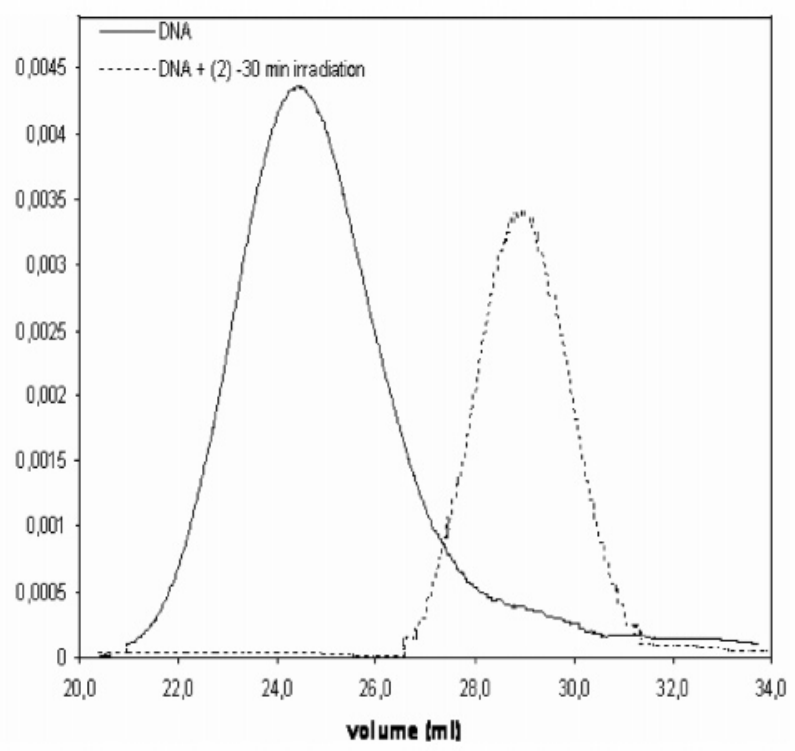

B.

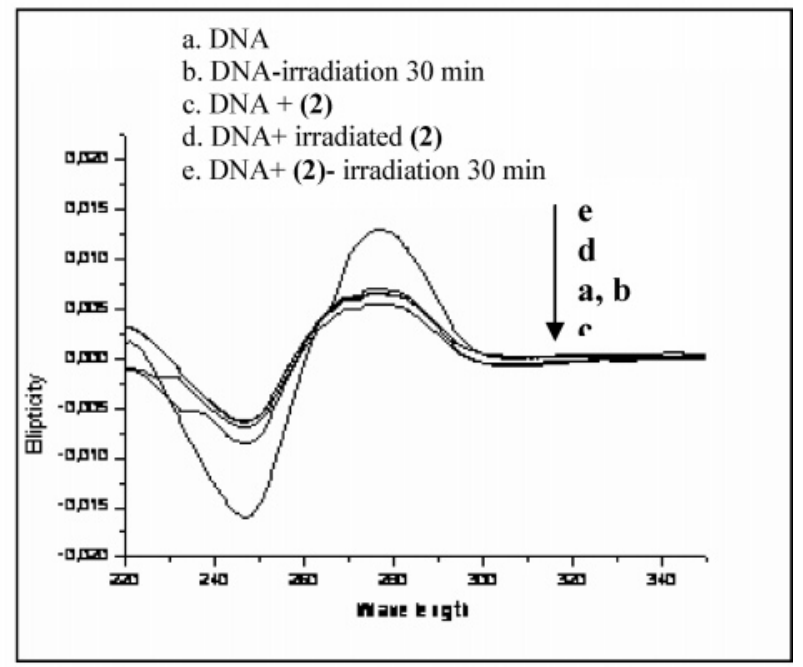

C.

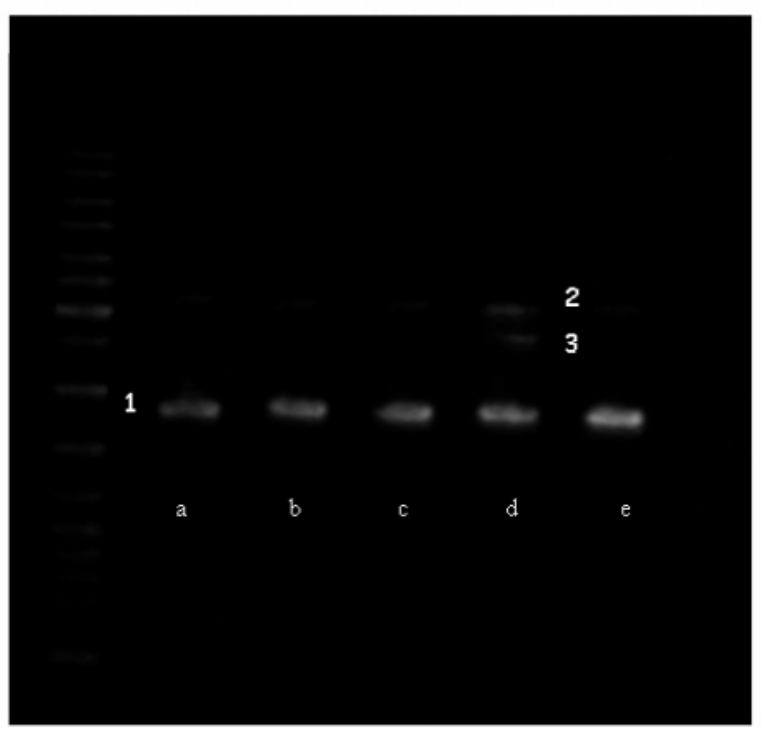

Figure 6. (A) Size exclusion chromatographic data of calf thymus DNA and the irradiated solution of DNA with complex 2. (B) Circular dichroism spectral changes of calf thymus DNA (70-300 bp) upon addition of complex 2 and irradiation. The arrow indicates the order from a to e. (C). Electrophoretic mobility results of the plasmid DNA pUC9 upon addition of complex 2: (a) supercoiled DNA; (b) irradiated supercoiled DNA for 30 min; (c) DNAcomplex (2), $r=0.25$; (d) DNA-complex (2), $r=0.25$, irradiated for $30 \mathrm{~min}$; (e) DNA-irradiated complex, lane 1, supercoiled DNA; lane 2, cleavage in single strand; lane 3 , cleavage in double strand linear.

nitrosyl complexes $\mathbf{1}$ and $\mathbf{3}$ at neutral $\mathrm{pH}$, where the DNA studies are performed, exist as nitro derivatives and for this reason only complexes $\mathbf{2}$ and $\mathbf{4}$ were studied.

The CD spectra of the short length calf thymus DNA, upon addition of the complexes at increasing ratios $(r=0.1,0.3$, and 0.5), are shown in Figure 4A. In general, complex 2 slightly affects the characteristic CD bands of B-type DNA, depending on the ratio. Upon ratio increase, the intensity of the positive band at $278 \mathrm{~nm}$ decreases (about $20 \%$ at ratio $r$ $=0.5$ ), while the band at $245 \mathrm{~nm}$ is remaining practically unaffected. Similar changes were obtained when double charged alkaline-earth metal cations interact at low concentrations with DNA, suggesting a shortening of the distance between the bottom of the major groove and the phosphate groups. ${ }^{56}$ Also, the triply positively charged cation $\left[\mathrm{Co}^{\mathrm{III}}\right.$ $\left.\left(\mathrm{NH}_{3}\right)_{6}\right]^{3+}$ has been found to induce similar changes in $\mathrm{CD}$ spectra of calf thymus DNA (160 and 3000-8000 bp) at low molar ratios $(<0.3)$. In this case, a dehydration process of the DNA was suggested, and therefore a decrease of its volume. ${ }^{57}$

The ${ }^{23} \mathrm{Na}$ NMR spectrum of complex 2 shows a line-width narrowing upon ratio increase from $r=0$ to $r=0.5(\Delta v 1 / 2$ $=23 \mathrm{~Hz}$ to $\Delta v 1 / 2=8 \mathrm{~Hz}$ ) (Figure $4 \mathrm{~B}$ ). This effect is consistent with a perturbation of the $\mathrm{Na}^{+}$counterions of the DNA phosphate groups. The positively charged complex interacts with DNA, and a modification of the total charge

(56) Kankia, B. I. Biophys. Chem. 2000, 84, 227.

(57) Kankia, B. I.; Buckin, V.; Bloomfield, V. A. Nucleic Acids Res. 2001, 29, 2795. 
of the DNA polyanion takes place. The replacing of the sodium ions from the DNA phosphates in complex $\mathbf{2}$ induces the narrowing in the ${ }^{23} \mathrm{Na} \mathrm{NMR}$ signal. However, the ${ }^{31} \mathrm{P}$ NMR spectra under the same conditions (Figure 4C) show a progressive broadening of the phosphorus resonance and a slight $(0.1 \mathrm{ppm})$ downfield shift, indicating an inflated dispersion of ${ }^{31} \mathrm{P}$ signals and a change in the ${ }^{31} \mathrm{P}$ environment. Taking into account that the DNA shortening observed by the circular dichroism data affects all the phosphate distances, it is suggested that the slight downfield shift may reflect the DNA shortening. The influence of the partial replacement of sodium counter ions, observed by the ${ }^{23} \mathrm{Na}$ NMR spectra, affects the surroundings of some phosphates, causing a dispersion of their chemical shifts. Also, it could be concluded that the reaction is in intermediately kinetics, in the NMR time scale at this temperature.

Complex 4 affects slightly both negative and positive CD bands of the DNA upon ratio increase (Figure 5A). The positive CD band at $278 \mathrm{~nm}$ is affected in a similar manner to complex 2, suggesting a reduction of the DNA length. However, the intensity of the band at $245 \mathrm{~nm}$ decreases, indicating that conformational alterations induced in DNA by complex $\mathbf{4}$ are different from those induced by complex 2. This observation was confirmed by the ${ }^{31} \mathrm{P}$ NMR spectra, which are different from those of complex 2, where a new signal appears, $3.4 \mathrm{ppm}$ downfield from the ${ }^{31} \mathrm{P}$ signal of the free DNA, accompanied by a broadening of the remaining signal (Figure 5C). Similar important downfield shifts were obtained in cases of strong DNA-ligand interactions, such as in the case of actinomycin, ${ }^{58}$ where a new signal was observed, due to the slow kinetics of the reaction. ${ }^{59}$ In the case of complex 4, slow kinetics could arise from the formation of hydrogen bonds or other interactions between the peptides and DNA. Since the ${ }^{23} \mathrm{Na}$ NMR data of the DNA titration with complex 4 (Figure 5B) follow those of complex $\mathbf{2}$, it is suggested that the peptide moiety binds to DNA in a synergistic way so that the whole complex binds.

(vi) Preliminary DNA Photocleavage Studies. Preliminary photocleavage studies of calf thymus and plasmid DNA were performed by irradiation of the DNA samples and complex $2(r=0.1)$ using a mercury lamp for $30 \mathrm{~min}$. Size exclusion chromatography was used to analyze the photoproducts. Thus, no difference in the molecular weight of calf thymus DNA alone after 30 min of irradiation was observed (126 KD). However, the chromatograph of an irradiated aqueous solution of CT DNA and complex 2 under the same

(58) Patel, D. J. Biopolymers 1976, 15, 533.

(59) Wilson, W. D.; Jones, R. L. Nucleic Acids Res. 1982, 10, 1399. conditions showed one peak corresponding to an average molecular weight of $30.2 \mathrm{KD}$, indicating that the DNA strands were photocleaved into shorter pieces (Figure 6A).

The CD spectrum of the irradiated calf thymus DNA and complex 2 shows a dramatic and almost equal increase in the intensities of both negative $(245 \mathrm{~nm})$ and positive (280 $\mathrm{nm}$ ) DNA bands, without any other alteration in the spectrum. (Figure 6B). The pattern of the CD spectrum produced indicates clearly a B-type form for the nicked DNA. ${ }^{60}$ In addition, no significant difference between the sample containing the separately irradiated $\mathbf{2}$ and DNA and the nonirradiated solution of DNA-complex 2 were observed (Figure 6B). The preliminary gel electrophoretic studies agree with the one of the $\mathrm{CD}$ spectra (Figure 6C).

A more detailed study of the photocleavage of CT DNA by complex 2 and other complexes is underway and will be published elsewhere.

\section{Conclusions}

In conclusion, this work has demonstrated the following: (i) The studied ruthenium nitrosyls are transformed to their nitro derivatives at neutral $\mathrm{pH}$ in solution. (ii) The photorelease of the $\mathrm{NO}$ in dry $\mathrm{MeCN}$ solutions produced solvolyzed photoproducts of $\mathrm{Ru}(\mathrm{III})$ which were detected. (iii) Complex 2 interacts with DNA and shortens slightly the DNA length. (iv) The conjugation of the peptide GHK to complex 2, however, results in a relatively tighter binding to DNA, with the peptide moiety acting in a synergistic way with the whole complex. Preliminary results have indicated photocleavage of CT DNA.

Acknowledgment. This work was supported by a Marie Curie Training Fellowship from the EU in the fifth Framework programme (MEDICINOR;Grant HPMT-CT-200000192), allowing one author (K.K.) to spend time at the LIC in Leiden to perform most of the experimental work. We thank COST action D20 for financial support of author K.K. on a short mission to the LIC in Leiden. Also, the Greek General Secretariat of Research and Technology is thanked for financial support (PENED 2001). Andrea Catte is kindly acknowledged for his help with the sonication of the CT DNA. K.K. would also like to thank the graduate program in Bioinorganic Chemistry of the University of Ioannina, coordinated by N.H.

IC0608039

(60) Ivanov, V. I.; Minchenk, L.; Schyolki, A.; Poletaye, A. Biopolymers $1973,12,89$. 